\title{
One Size Fits Some
}

\section{: A Reassessment of EMU's Core-periphery Framework}

\author{
Marcus Wortmann \\ Georg-August-University Göttingen, Göttingen, Germany \\ Markus Stahl \\ Georg-August-University Göttingen, Göttingen, Germany
}

\begin{abstract}
This study provides a new multivariate assessment of core-periphery structures within the European Union. By applying different cluster algorithms to the broad set of Macroeconomic Imbalance Procedure indicators, we detect a relatively stability-oriented and homogeneous group of European Union core countries that would be suitable for having a common currency. Unlike previous results, our analysis shows that countries such as the United Kingdom, Denmark, and Sweden would also fit well within such a hypothetical euro area. However, Greece, Ireland, Italy, Portugal, and Spain plus Cyprus and Croatia on the southern periphery, as well as most of the countries of the eastern enlargement are found to form very distinct clusters in terms of competitiveness, indebtedness, and economic performance. Our findings thus reveal that a single monetary policy can be appropriate only for some countries, even when measured using the official Macroeconomic Imbalance Procedure scoreboard specifically designed to monitor the smooth functioning of the Economic and Monetary Union.
\end{abstract}

\footnotetext{
* Corresponding Author: Marcus Wortmann; Georg-August-University Göttingen, Platz der Göttinger Sieben 3, 37073 Göttingen, Germany; Tel: +49 (0) 55139 7355, Fax: +49 (0) 55139 7093, E-mail: marcus.wortmann@wiwi.unigoettingen.de.

Co-author: Markus Stahl; Georg-August-University Göttingen, Platz der Göttinger Sieben 3, 37073 Göttingen, Germany; Tel: +49 (0) 55139 7337, Fax:+49 (0) 55139 7093, E-mail: markus.stahl@wiwi.uni-goettingen.de.
} 
JEL Classifications: C38, F15, F45, O57

Keywords: Economic and Monetary Union, Macroeconomic Imbalance Procedure, Economic Integration, Macroeconomic Disparities, Cluster Analysis

\section{Introduction}

The ongoing crisis of the euro area shows that even after 16 years of common currency, a one size fits all monetary policy cannot be conducted smoothly in a distinct coreperiphery framework. Even though many economists warned early-on against the rapid introduction of the euro within a large heterogeneous group of insufficiently prepared economies, ${ }^{1}$ the famous endogenous theory of Frankel and Rose (1998) raised hopes of ultimately overcoming any disparities. So far, this remains a vision, and the initially claimed stability orientation ${ }^{2}$ - marked by similar and low inflation, a stable exchange rate, and sustainable debt levels - remains out of sight. Instead, the monetary union itself fostered macroeconomic imbalances both within and between Greece, Ireland, Italy, Portugal, Spain (GIIPS countries) in the south and the core countries in the north. Large economic disparities in terms of competitiveness, indebtedness, and economic performance have put the European Central Bank (ECB) in a desperate position: while, for instance, many countries in the latter group now need a stronger euro and higher interest rates, the opposite holds for the southern periphery. However, during the crisis, the ECB found itself forced to apply an expansive monetary policy aiming to support the GIIPS countries' struggle for recovery, simultaneously fighting an alleged deflation risk. This recent monetary policy has often been criticized by the core countries for its negative effects on domestic savings, price bubbles, and the ECB's balance sheet, as well as for dangerous fiscal debt financing, which in turn will establish negative incentives for budgetary discipline and the necessary structural reforms. In addition to the one size fits some monetary policy described above, the European Union (EU) has also introduced the European Stability Mechanism (ESM) for highly indebted countries, as well as other

\footnotetext{
${ }^{1}$ Feldstein (1997), p. 41. The critique of German economists can be found in the Financial Times of February 9, 1998: "The Euro starts too early." Jonung and Drea (2010) provide an extensive overview of critical American economists.

${ }^{2}$ The concept of a stability orientation was put forward by the German Federal Constitutional Court as a precondition for Germany's participation in the EMU in the Maastricht Judgement (BVerfGE 89, 155, October 12, 1993, Az: 2 BvR 2134, 2159/92).
} 
measures aimed at addressing high youth unemployment and low investment activity on the southern periphery. The reassessment of core-periphery structures is thus important not only for establishing a proper monetary policy but also for developing common economic policy strategies to overcome tenuous disparities.

The following analyses provide a clear data-based picture of core-periphery structures, depicting more precisely what is often thought of as a simple north-eastsouth division. To do so, we follow a multidimensional approach rather than only looking at, for example, output synchronization, as is often done to distinguish between core and peripheral areas within the Economic and Monetary Union (EMU). Instead, we apply different cluster algorithms and Principal Components Analysis (PCA) to the Macroeconomic Imbalance Procedure (MIP) indicator set, which was designed to capture the most relevant economic developments responsible for the smooth functioning of EMU (European Commission 2012). As these indicators were chosen against the background of the euro area crisis experience, we believe cluster analysis on this basis to be a new and reasonable approach to assess the core-periphery dynamics of the EMU. Moreover, the MIP scoreboard includes data for every EU member state and thus allows us to identify a relatively stability-oriented and homogeneous group of EU core countries that are theoretically suitable for a common currency. Our results provide an economic indication of how well the current EMU members and outsiders fit into the currency area. While our findings suggest that countries such as the United Kingdom (UK), Denmark, and Sweden could easily share a common currency with the core countries, others, such as the GIIPS countries, clearly require different treatment. With respect to the appropriate level of integration, this article provides new impetus to the recently heated debates about Greek Exit (GREXIT) from the euro area and British Exit (BREXIT) from the EU. Therefore, we analyze the magnitude and similarity of internal and external imbalances to contribute to academic and political solution strategies to the euro crisis.

The remainder of this study is organized as follows. Section II first introduces the existing literature on core-periphery dynamics in the EMU. Then, we explain why the MIP scoreboard provides a proper basis for assessing the underlying disparities. The methodology and data are introduced in Section III, followed by the presentation of the results of the cluster analyses and PCA in Section IV. Section V addresses the policy implications and Section VI concludes. 


\section{Macroeconomic Imbalance Procedure}

This article contributes to the literature on core-periphery dynamics, especially those related to European monetary integration. Before the introduction of the euro in 1999, it was questioned as to which countries would belong to a promising core group or periphery in light of the optimum currency area theory (Bayoumi and Eichengreen 1993, 1994, 1997). In contrast, the theory of an endogenous currency area proposed by Frankel and Rose (1998) states that potential member countries did not have to fulfill certain optimal conditions ex ante but would rather form an optimal currency area ex post. Advocates of the endogeneity hypothesis saw a positive correlation between trade integration and output synchronization as monetary unification itself would increase intra-industry trade flows. Economic theory, however, suggests that economic integration could lead to more specialization and increased inter-industry trade, facilitating asymmetric supply shocks (Caporale et al. 2014). In this theoretical controversy, Europe's business cycle synchronization has usually been the focus of empirical investigation and is seen as a meta criterion for an optimal currency area (Mongelli 2008, de Haan et al. 2007). If shocks and business cycles were found to converge in the EMU, this was interpreted as support for the endogenous view (Gachter and Riedl 2014). However, other studies discovered decreasing output synchronization and a diverging pattern of core and peripheral areas (Pentecote and Huchet-Bourdon 2012, Caporale et al. 2014, Lehwald 2013).

When the euro crisis emerged in 2010, other dimensions of the core-periphery division of EMU came back into academic focus. Macroeconomic imbalances in and between southern and northern EMU member states concerning competitiveness, indebtedness, and economic performance became apparent and required some rootcause analysis to enhance future governance (for a discussion of the interdependence of different crises, see Shambaugh 2012). The formerly weak-currency countries of the southern periphery experienced extensive capital inflows due to the removal of risk premia in the run-up to EMU. While this facilitated public and private sector consumption, it rarely led to investment-driven productivity gains. Prices and wages in these countries did rise, but they subsequently lost their competitiveness and built up persistent current account deficits that could no longer be reduced by nominal depreciation (Fischer and Hobza 2014). The GIIPS countries eventually experienced slow growth, high unemployment, and deflationary pressures after the global financial 
crisis (Eichengreen 2010), but many often-labeled core countries, such as Germany, Austria, and the Netherlands, were able to recover much faster. The hope of an endogenous monetary union which could, in the meantime, find some support in business cycle patterns (European Commission 2008) gave way to an alarming divergence in output gaps between core and peripheral countries (European Commission 2014a).

Current disparities between EMU member states are closely related to certain internal imbalances. The consumptive use of capital inflows in the non-tradeable sector, which triggered housing price bubbles in Ireland and Spain, as well as extensive private and public debt accumulation, contributed to worsening current account deficits and international investment positions of the GIIPS countries (Fischer and Hobza 2014). The resulting debt crisis documented again that monetary integration itself created incentives and opportunities for the south to finance demand-side growth by borrowing from the north (Hall 2012). Although such group dynamic effects of public debt in a monetary union (Beetsma and Uhlig 1999), as well as the respective incentives to free ride, were clear from the beginning (Horstmann and Schneider 1994, Ohr 2004), all institutional arrangements to ensure stability proved to be insufficient to resolve — or even instead exacerbate - the public debt crisis (Lane 2012).

In 2011, the EU introduced MIP as a new governance tool to monitor and correct future imbalances. The MIP scoreboard of 11 macroeconomic indicators, together with critical thresholds, offers a substantial and eligible database to investigate the EU's coreperiphery structures as it transforms the multidimensional developments described above into measureable criteria essential for the smooth functioning of a monetary union. Moreover, these criteria not only include a mix of flows and stocks, as well as nominal and real figures, but also capture backward moving averages, which make them more robust to short-term fluctuations. The indicators are as follows: ${ }^{3}$

- Three-year backward-moving average of the current account balance in percentage of GDP, with a threshold of $+6 \%$ and $-4 \%$;

- Net international investment position in percentage of GDP, with a threshold of $-35 \%$;

- Five-year percentage change in export market shares measured in values, with a threshold of $-6 \%$;

- Three-year percentage change in nominal unit labor cost, with thresholds of $+9 \%$ for euroarea countries and $+12 \%$ for non-euro area countries, respectively;

\footnotetext{
${ }^{3}$ Scoreboard summary taken from European Commission (2012) and Fischer and Hobza (2014). See both for further details on indicators and the design of the MIP. The 2013 MIP scoreboard can be found in Table 1.
} 
- Three-year percentage change in real effective exchange rates based on HICP/CPI deflators, relative to 35 other industrial countries, with thresholds of $\pm 5 \%$ for euro-area countries and $\pm 11 \%$ for non-euro area countries, respectively;

- Private-sector debt in percentage of GDP, with a threshold of $160 \%$;

- Private-sector credit flow in percentage of GDP, with a threshold of $15 \%$;

- Year-on-year changes in the house price index relative to a Eurostat consumption deflator, with a threshold of $6 \%$;

- General government sector debt in percentage of GDP, with a threshold of $60 \%$;

- Three-year backward moving average of the unemployment rate, with a threshold of $10 \%$; and

- Annual growth rate of total financial sector liabilities, with a threshold of $16.5 \%$.

The MIP was designed as an early warning system that would detect risks for the monetary union as a whole. If the commission encounters violations of certain thresholds, it provides in-depth reviews and action plans for corrective policy measures in the affected countries. In the case of non-compliance, sanctions can be imposed on EMU member states as a last resort. This procedure focuses on country-specific imbalances measured by absolute indicator values. It is, of course, a legitimate approach concerning internal and external stability matters but does not check for the homogeneity of country values as another precondition of a smoothly working monetary union. From this viewpoint, a large current account surplus, as seen in Germany, can only be judged as an excessive imbalance if most of the other member states do not have similar surpluses (Gros and Giovannini 2014). Therefore, for the purpose of this study, we follow a relative perspective and consider between-country disparities of MIP indicators as risks for the stability and efficiency of EMU. Hence, the lower the disparities in real exchange rates, current account balances, unit labor costs, and unemployment, the more possible it will be to define a one size fits all monetary policy. In addition, the monetary transmission channels will work better if private-sector credit flows are fairly similar. Finally, the more alike private and public sector indebtedness levels are, the lower the risks of country-specific confidence losses, sudden liquidity stops, spillover effects, and the need for financial support or monetary action to bail out other EMU member states.

To identify relatively homogeneous groups of core and peripheral countries based on the MIP indicators, we now employ different cluster methods, which are yet to be

\footnotetext{
${ }^{4}$ Gruber and Ohr (2001) discuss the relevance of different financing structures and monetary transmission channels for the functioning of a monetary union.
} 
used in this context. For instance, König and Ohr (2013) and Rozmahel et al. (2013) recently used hierarchical cluster analyses to uncover some multidimensional politicoeconomic forms of heterogeneity in the EU. Quah (2014) groups EU countries based on their business cycle synchronicities with the euro area using a fuzzy clustering technique. Considering specifically the core-periphery division of EMU with the help of some optimal currency area criteria, Artis and Zhang's (2001) cluster analysis revealed that at the time, only five of the $13 \mathrm{EU}$ countries under investigation formed a suitable core group (France, Netherlands, Belgium, Austria, and Germany). The same authors (Artis and Zhang 2002) later applied another cluster technique to the Maastricht convergence criteria, adding Italy, Spain, and Portugal to the core cluster. Based on this work, Boreiko (2003) and Kozluk (2005) studied the readiness of Eastern European candidate countries for EMU membership using cluster analyses. Artis and Zhang (2001) formerly concluded: A finding of inhomogeneity in the ranks of the putative EMU must suggest that a one-size-fits-all monetary policy will be appropriate to certain member countries and could threaten the union's sustainability. A key issue here, which this analysis cannot comment upon, is how far this problem will prove transitory (as the endogeneity literature suggests) or, on the other hand, persistent.

Taking this as a case for reassessment, we now, after 16 years of monetary union and five years of the euro-area crisis, shed some light on the current scenario. 


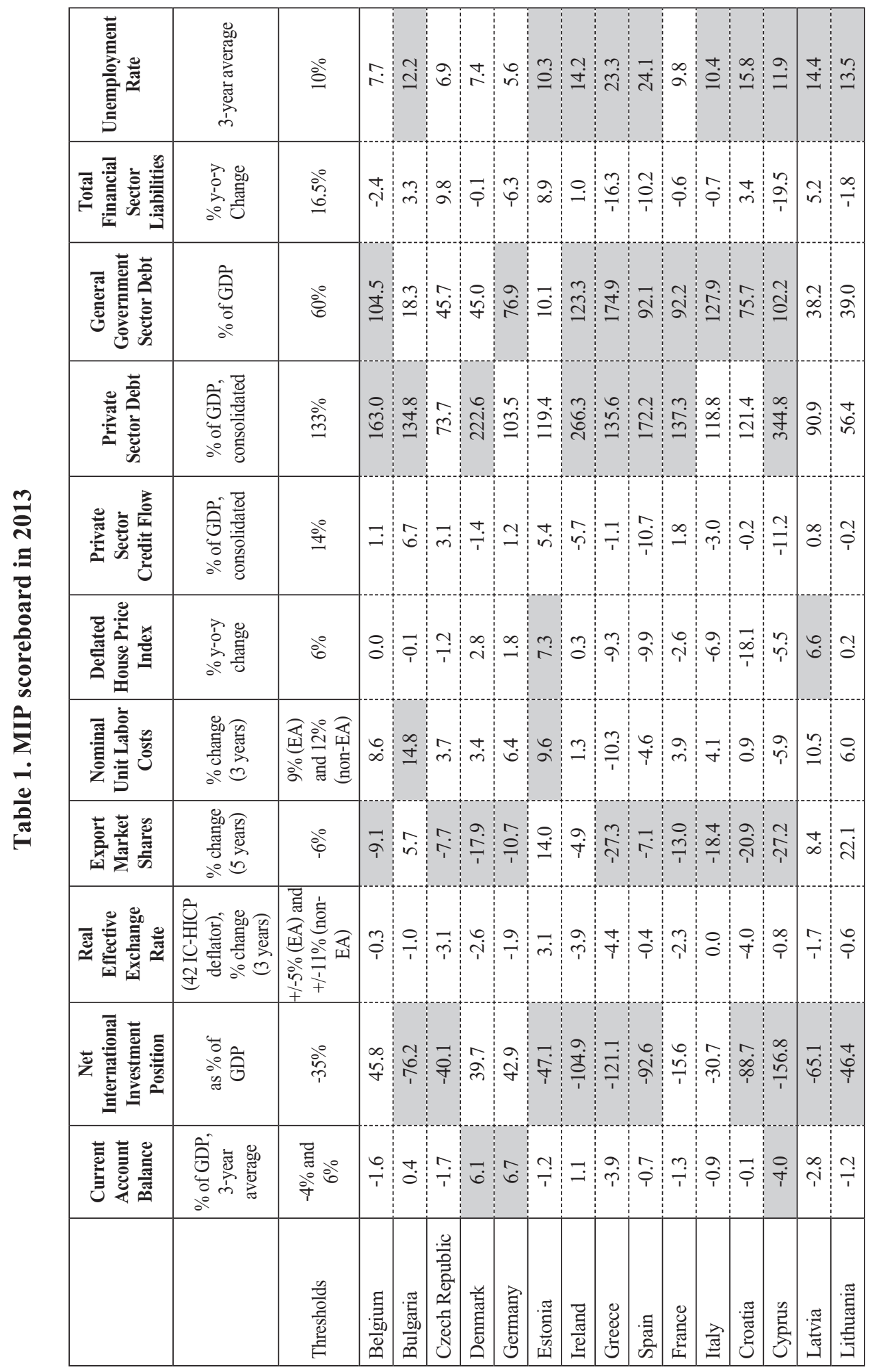




\begin{tabular}{|c|c|c|c|c|c|c|c|c|c|c|c|c|c|c|c|c|c|c|c|}
\hline 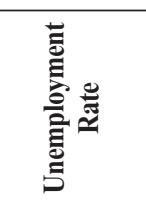 & 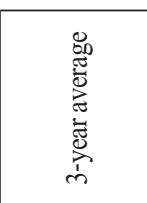 & ఏे & ?n & $\hat{0}$ & ષ্் & $\begin{array}{l}n \\
n\end{array}$ & $\begin{array}{l}n \\
\forall\end{array}$ & c & $\begin{array}{l}\text { in } \\
\text { in }\end{array}$ & ? & 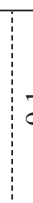 & & i & $\stackrel{9}{\square}$ & 9 & 9 & $\hat{\theta}$ & $\stackrel{\text { İ }}{\Xi}$ & 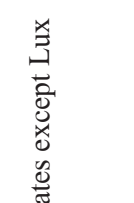 \\
\hline 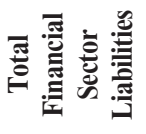 & 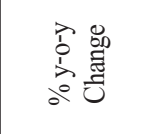 & 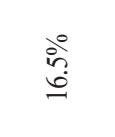 & $\begin{array}{l}\infty \\
\infty \\
\infty\end{array}$ & $\stackrel{?}{?}$ & $\hat{0}$ & $\frac{r}{r}$ & $\begin{array}{l}0 \\
\end{array}$ & $?$ & in & $\bar{c}$ & & ? & $?$ & $\stackrel{\infty}{\square}$ & $\sigma$ & ${ }_{T}^{+}$ & $\frac{\infty}{\top}$ & $\stackrel{\ddot{r}}{\dot{p}}$ & $\begin{array}{l}\bar{D} \\
\text { है } \\
\text { है }\end{array}$ \\
\hline 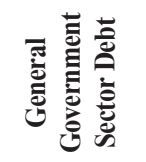 & \begin{tabular}{l} 
今ิ \\
\multirow{4}{\circ}{} \\
$0^{\circ}$
\end{tabular} & ठิ & $\begin{array}{l}0 \\
\text { ते }\end{array}$ & $\stackrel{?}{\stackrel{2}{r}}$ & $\begin{array}{l}\infty \\
\ddot{0} \\
\text { d. }\end{array}$ & $\begin{array}{l}0 \\
\infty \\
0\end{array}$ & $\frac{N}{\infty}$ & in & $\begin{array}{l}\infty \\
\text { d }\end{array}$ & in & & t. & : & 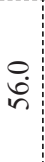 & $\begin{array}{l}0 \\
\infty \\
\infty\end{array}$ & $\frac{1}{\infty}$ & $\begin{array}{l}\infty \\
\kappa\end{array}$ & & 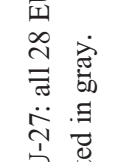 \\
\hline 芯 & 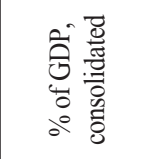 & लें & $\begin{array}{l}n \\
\tilde{n} \\
n \\
n\end{array}$ & $\stackrel{n}{\alpha}$ & $\stackrel{\overrightarrow{0}}{\stackrel{0}{n}}$ & ปे & $\begin{array}{l}n \\
ٌ\end{array}$ & $\frac{\pi}{t}$ & $\begin{array}{l}\infty \\
\tilde{c}\end{array}$ & 5 & & 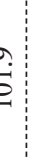 & 送 & $\begin{array}{l}0 \\
\stackrel{0}{0} \\
\stackrel{ \pm}{ \pm}\end{array}$ & 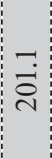 & \begin{tabular}{l}
$n$ \\
\multirow{\sigma}{*}{}
\end{tabular} & $\begin{array}{l}\infty \\
\stackrel{D}{J}\end{array}$ & 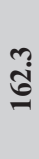 & 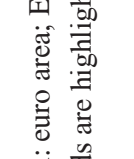 \\
\hline 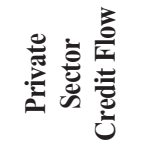 & 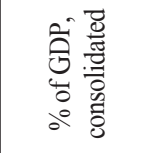 & $\stackrel{\circ}{\dot{\Xi}}$ & $\stackrel{\grave{\lambda}}{\grave{\lambda}}$ & $\frac{0}{T}$ & $\stackrel{\nabla}{0}$ & $\vec{\sim}$ & $\stackrel{\Im}{0}$ & $\stackrel{2}{2}$ & $\stackrel{ナ}{\curvearrowright}$ & 4 & & P & r. & $\ddot{0}$ & $\ddot{m}$ & $\stackrel{\vec{m}}{\circ}$ & $\overline{9}$ & $\stackrel{t}{\Theta}$ & 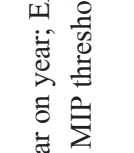 \\
\hline 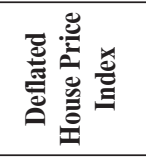 & 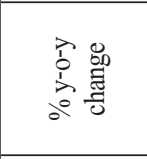 & iें & $\dot{+}$ & ن. & $\vec{i}$ & $\stackrel{\infty}{\uparrow}$ & $\sqrt[n]{\mathrm{i}}$ & 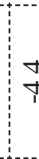 & $\tilde{r}$ & 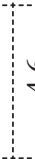 & & ن. & $?$ & $\stackrel{?}{-1}$ & F & $\stackrel{0}{-}$ & ஸे & نْ & 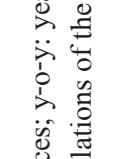 \\
\hline 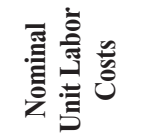 & 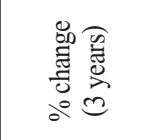 & 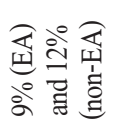 & $\ddot{n}$ & में & $\tilde{a}$ & ? & : & ले & ç & 7 & & $?$ & n. & $\tilde{a}$ & $\infty$ & $\infty^{\infty}$ & $\stackrel{\odot}{+}$ & $\stackrel{\infty}{\leftrightarrow}$ & 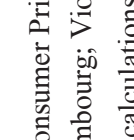 \\
\hline 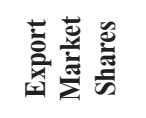 & 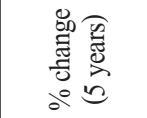 & ọं & त̃ & $\frac{2}{1}$ & $\stackrel{\circ}{\underset{十}{+}}$ & & $\stackrel{\circ}{\circ}$ & $\underset{i}{\vec{T}}$ & is & 5 & 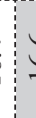 & : & $\underset{y}{y}$ & $\begin{array}{c}\widetilde{Z} \\
\widetilde{r}\end{array}$ & $\begin{array}{l}0 \\
\frac{1}{1}\end{array}$ & $\frac{F}{7}$ & $\begin{array}{l}n \\
\infty\end{array}$ & $\underset{0}{0}$ & 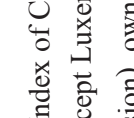 \\
\hline 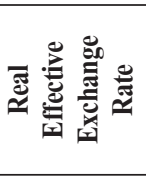 & 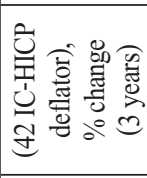 & 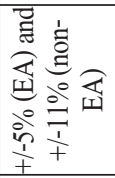 & $\overrightarrow{0}$ & $\stackrel{\circ}{\stackrel{P}{i}}$ & $\stackrel{m}{\rightarrow}$ & $\stackrel{+}{\circ}$ & $\hat{0}$ & $\stackrel{P}{7}$ & ? & ช & & $\dot{p}$ & $\overrightarrow{\mathrm{v}}$ & $\overrightarrow{0}$ & $\vec{n}$ & $\stackrel{+}{\infty}$ & 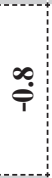 & : & 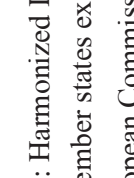 \\
\hline 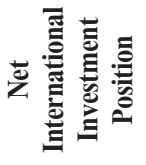 & 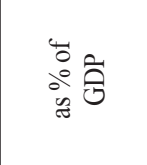 & ڤें & $\begin{array}{l}\dot{\theta} \\
\dot{\sigma} \\
\sim\end{array}$ & $\stackrel{+}{\stackrel{+}{+}}$ & ra & $\frac{m}{m}$ & ָै & $\begin{array}{c}\underset{c}{\alpha} \\
\underset{1}{\alpha}\end{array}$ & $\frac{\tilde{f}}{7}$ & s & & ب. & 6. & $\begin{array}{l}\infty \\
\infty \\
\infty\end{array}$ & $\begin{array}{l}\infty \\
0 \\
\end{array}$ & $\begin{array}{l}0 \\
\frac{1}{1}\end{array}$ & $\frac{\infty}{f}$ & ث̊. & 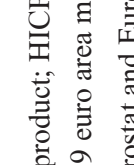 \\
\hline 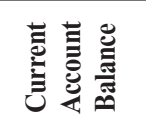 & 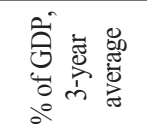 & 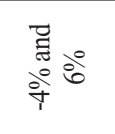 & $\begin{array}{l}n \\
\text { in }\end{array}$ & 고 & $\stackrel{\circ}{+}$ & $\stackrel{\infty}{a}$ & $\stackrel{+}{ \pm}$ & r) & $\tilde{n}$ & 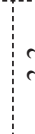 & & $\stackrel{\circ}{i}$ & "y. & $\stackrel{T}{T}$ & 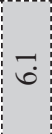 & $\begin{array}{c}1 \\
p\end{array}$ & $\stackrel{9}{9}$ & $\stackrel{n}{8}$ & 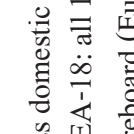 \\
\hline & & 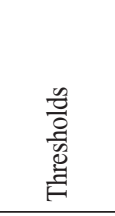 & 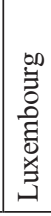 & 票 & $\stackrel{\frac{\pi}{\pi}}{\Sigma}$ & 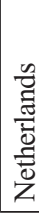 & 恶 & a & 送 & & & & 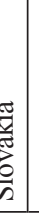 & 袢 & 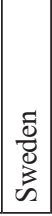 & 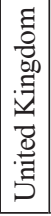 & 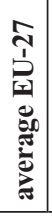 & 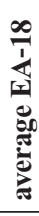 & 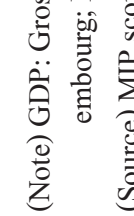 \\
\hline
\end{tabular}




\section{Data and Methodology}

The extensive data bank of the European Commission and Eurostat for the main 11 MIP scoreboard indicators and some auxiliary indicators serve as the basis of the following analysis in Section IV and Section V. At the time of writing, complete annual scoreboard data are available for all 28 EU member states from 2004 to 2013. This period will be sufficient to investigate the effects of the global financial crisis, as well as of the euro-area crisis, on the EMU's core-periphery setting over time.

Previous empirical research employed the scoreboard indicators to predict crises and find optimal country group-specific thresholds to improve the performance of the early warning system. Therefore, Logit/Probit models and neural network analysis have been used, whereas the latter explicitly accounts for the interaction of variables (Knedlik 2015). In contrast to this literature, we make use of the scoreboard data to assess the degree of heterogeneity across EU member states.

To identify homogeneous groups within a population of objects (here countries) based on several features (here indicators), two different cluster methods are applied. First, a hierarchical agglomerative procedure is used to identify a reasonable grouping. Then, we perform a partitioning method to check the sensitivity of the first result. The algorithms used — Ward's method and Fuzzy C-Means (FCM) — are briefly described in the following pages, focusing on why these procedures were chosen (Kaufman und Rousseeuw 2005). The data were first standardized to eliminate differences in scale and treat all indicators as having the same weight.

The algorithms are based on the measurement of the squared Euclidean distance between two objects $i$ and $h$ :

$$
d=\left(x_{i}-x_{h}\right)^{2}=\sum_{k=1}^{p}\left(x_{i k}-x_{h k}\right)^{2}
$$

For all features $(\mathrm{k}=1, \ldots, p)$, the pairwise differences in the observed values $x_{i k}$ (for $\mathrm{i}=1, \ldots, n)$ are squared and afterwards summed. This yields an $n \times n$ distance matrix with each country initially forming a separate cluster.

In the first step of the Ward approach, the two countries with the smallest squared Euclidean distance between them are paired. Then, the distance of the resulting first cluster to all the other objects must be recalculated. The shortest distance is essentially 
calculated so that the smallest increase in heterogeneity would arise in the new cluster after merging different objects or clusters. This heterogeneity within formed clusters can be determined based on the sum of squared errors $(\mathrm{V})$ of a cluster $j$ :

$$
V_{j}=\sum_{i=1}^{n_{j}} \sum_{k=1}^{p}\left(x_{i k j}-\bar{x}_{k j}\right)^{2}
$$

with $x_{i k j}=$ observation of indicator $k$ of country $i$ (for every country in cluster $j$ ) $x_{k j}=$ mean of indicator $k$ in cluster $j$

If there are $n$ individual clusters at the starting point, the sum of squared errors is zero in each case as no variation within the cluster exists. In each step of the process, the distance between object or cluster $\mathrm{A}$ and a new cluster $(\mathrm{B}+\mathrm{C})$ is updated using the following equation:

$$
D(A ; B+C)=\frac{1}{n^{A}+n^{B}+n^{C}} *\left\{\left(n^{A}+n^{B}\right) * d(A ; B)+\left(n^{A}+n^{C}\right) * d(A ; C)-n^{A} * d(B ; C)\right\}
$$

with $n^{A}, n^{B}, n^{C}=$ number of objects in clusters A, B, and C

where D is here twice the increase in the sum of squared errors in Equation (2). If every time the specific objects and clusters with the smallest distance between them are combined, only one cluster exists in the end, which includes all objects (Backhaus et al. 2008).

Ward's method is often regarded as the best hierarchical clustering algorithm as the true grouping in the data can reliably be identified (Bergs 1981). It also tends to form equal group sizes, so its use in the context of core-periphery structures seems sensible. However, the grouping results in Section IV can be replicated in a very similar manner using the average linkage method (see Appendix 1).

A general problem in cluster analysis is determining the optimal number of clusters corresponding to the data as far as possible. As there is usually no substantive information on the accuracy of the number of clusters that should be chosen, several statistical test criteria can be used to provide a more objective definition. For instance, when applying Ward's method, we can use the Calinski-Harabasz pseudo F-test (Backhaus et al. 2008). However, in our case, with only 19 or 28 objects, it is also possible to check the optimal number of clusters through plausible assumptions. While Ward's method also makes it 
possible to choose a proper classification visually using the dendrogram, with the FCM algorithm the number of clusters must be determined ex ante, so that the results vary depending on the initial setting. Concerning the data corresponding to best choice, there is a wide literature on cluster validity (Whang and Zhang 2007).The FCM algorithm used here goes back to Bezdek (1981). In contrast to the clear assignment of an object to a cluster with hard clustering, in fuzzy logic, a degree of membership $u_{i j}$ is determined for each object $i$ in all clusters $j$. Hence, a fuzzy partition matrix $U_{c x n}$ is formed with $\sum_{j=1}^{C} u_{i j}=1$. The aim of this procedure is to recalculate the position of the predetermined number of cluster centers and the membership degrees iteratively, so that at the end of the process, no further improvement in the cluster assignment is possible.

To this end, the objective function

$$
J(U, V)=\sum_{i=1}^{n} \sum_{j=1}^{c} u_{i j}^{m}\left\|x_{i}-v_{j}\right\|^{2}
$$

must be minimized. ${ }^{5}$ Here, $u$ denotes the degree of membership of a country $i$ in cluster $j$ and $\left\|x_{i}-v_{j}\right\|^{2}$ is the squared Euclidean distance between country $i$ and cluster center $v$. We can use Equation (5) and Equation (6)

$$
\begin{gathered}
V_{j}=\frac{\sum_{i=1}^{n}\left(u_{i j}\right)^{m} x_{i}}{\sum_{i=1}^{n}\left(u_{i j}\right)^{m}}, 1 \leq j \leq c \\
u_{i j}=\left[\sum_{g=1}^{c}\left(\frac{\left\|x_{i}-v_{j}\right\|^{2}}{\left\|x_{i}-v_{g}\right\|^{2}}\right)^{1 /(m-1)}\right]^{-1}, 1 \leq j \leq c, 1 \leq i \leq n
\end{gathered}
$$

to minimize the objective function. (Wang and Zhang 2007)

\footnotetext{
${ }^{5}$ The $m$ parameter has an influence on how clearly the cluster allocation to the objects appears. In the following analysis, it is set to the value of 2 .
} 


\section{Results}

\section{A. Results of the Ward algorithm}

First, an agglomerative cluster analysis is undertaken of all current EU member states for the year 2013 using the Ward algorithm. Figure 1 shows the results of this analysis in the form of a dendrogram. It can immediately be seen that three different groups of countries ${ }^{6}$ are identified at a distance of 37-apart from Luxembourg, which can be assessed in many ways as an outlier. ${ }^{7}$ The cluster at the bottom of the dendrogram comprises Belgium, France, Austria, Italy, Finland, Hungary, Slovenia, Slovakia, the UK, Denmark, Germany, Malta, the Netherlands, and Sweden. As this group primarily consists of powerful economies in Central and Northern Europe, it will be referred to as the core group hereafter.

\footnotetext{
${ }^{6}$ Also, the Calinski-Harabasz pseudo $F$-test indicates a reasonable number of four clusters (with Luxembourg).

${ }^{7}$ In particular, due to the net international investment position, private-sector credit flow, and private-sector debt (see Table 1).

${ }^{8}$ Although even core group countries exceed MIP thresholds (see Table 3 below), this cluster best fits the requirements of a stable monetary union.
} 
Figure 1. Dendrogram of the cluster analysis for the EU in 2013

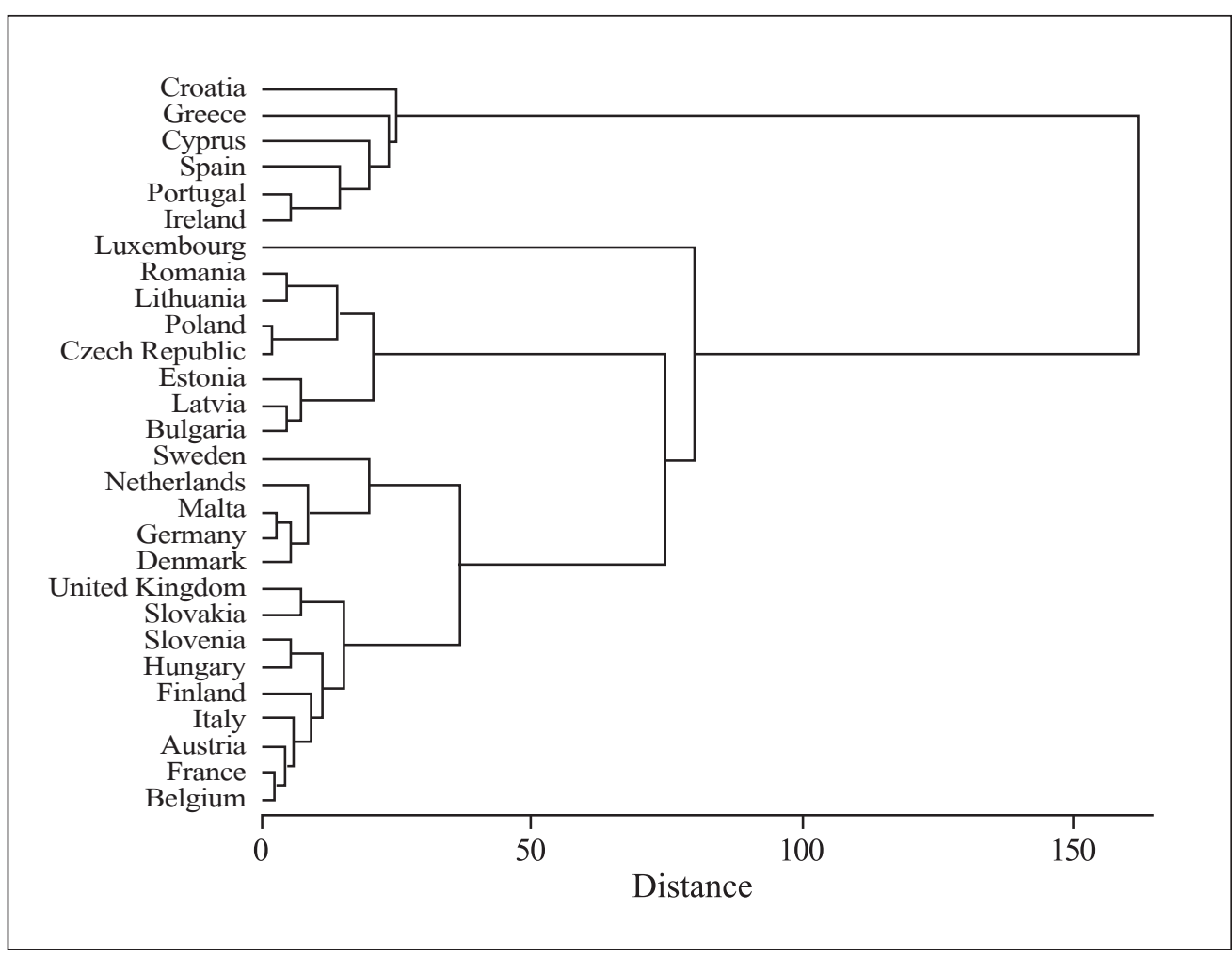

(Note) Cluster analysis using the Ward algorithm.

(Source) MIP scoreboard (Eurostat and European Commission), own calculations and presentation.

Countries of the EU enlargement (Bulgaria, Latvia, Estonia, Czech Republic, Poland, Lithuania, and Romania) are clustered with some distance into an eastern periphery group. Finally, at a further considerable distance, a group often referred to as the Greece, Ireland, Portugal, and Spain (GIPS countries) together with Cyprus and Croatia, is located at the top of the dendrogram. This cluster may be labeled as the southern periphery because it includes primarily those countries most affected by the euro-area crisis and partly dependent on EU assistance. Today, the euro area with its 19 members comprises the majority of countries in the core group and those of the southern periphery (except Croatia). It thus comprises two groups of countries with extremely different economic conditions. This result confirms the intuitively used core-periphery structure during the euro area crisis and proves cluster analysis based on the MIP indicators is a proper empirical tool for examining the functioning of EMU. 
Figure 2. Evolution of clusters in the euro area from 2004 to 2013

Figure 2a: Euro area 2004

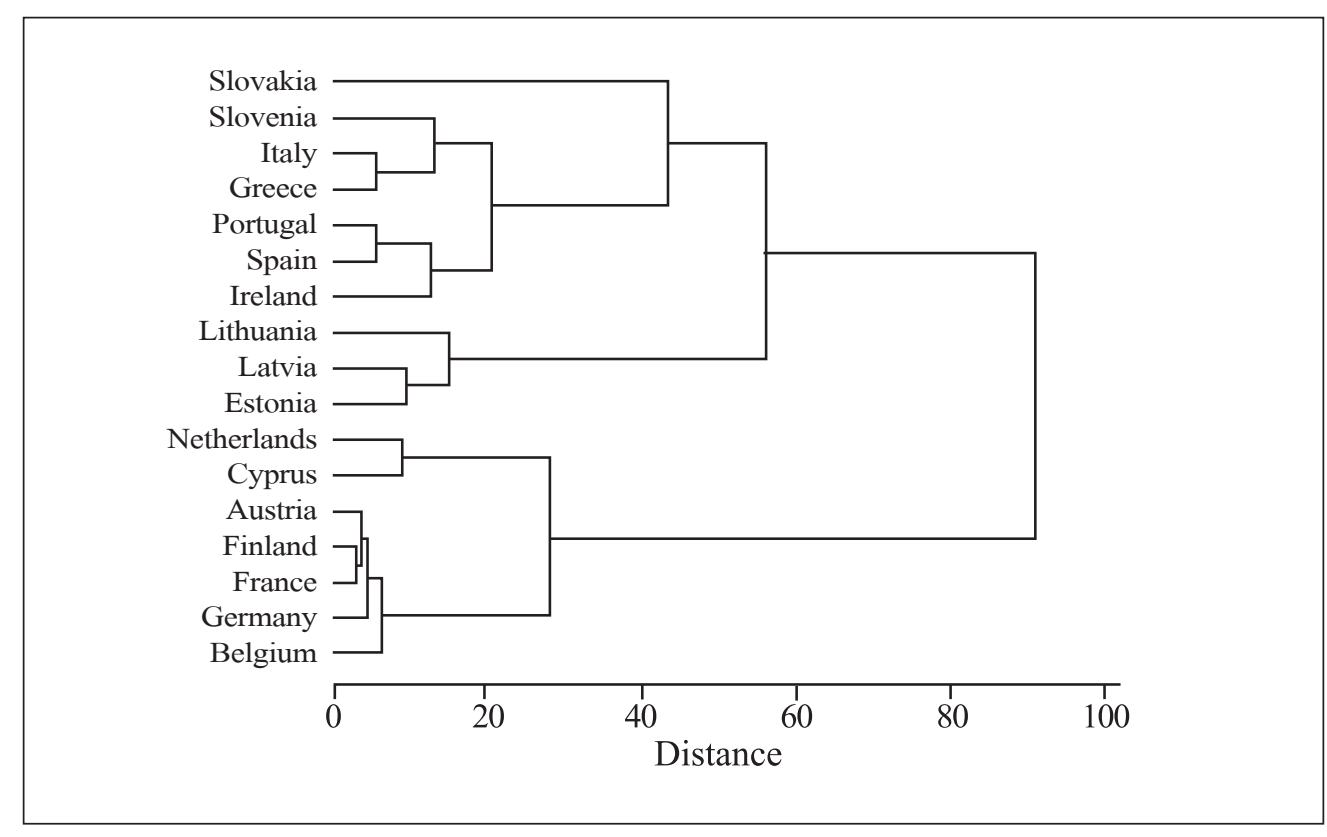

Figure 2b: Euro area 2007

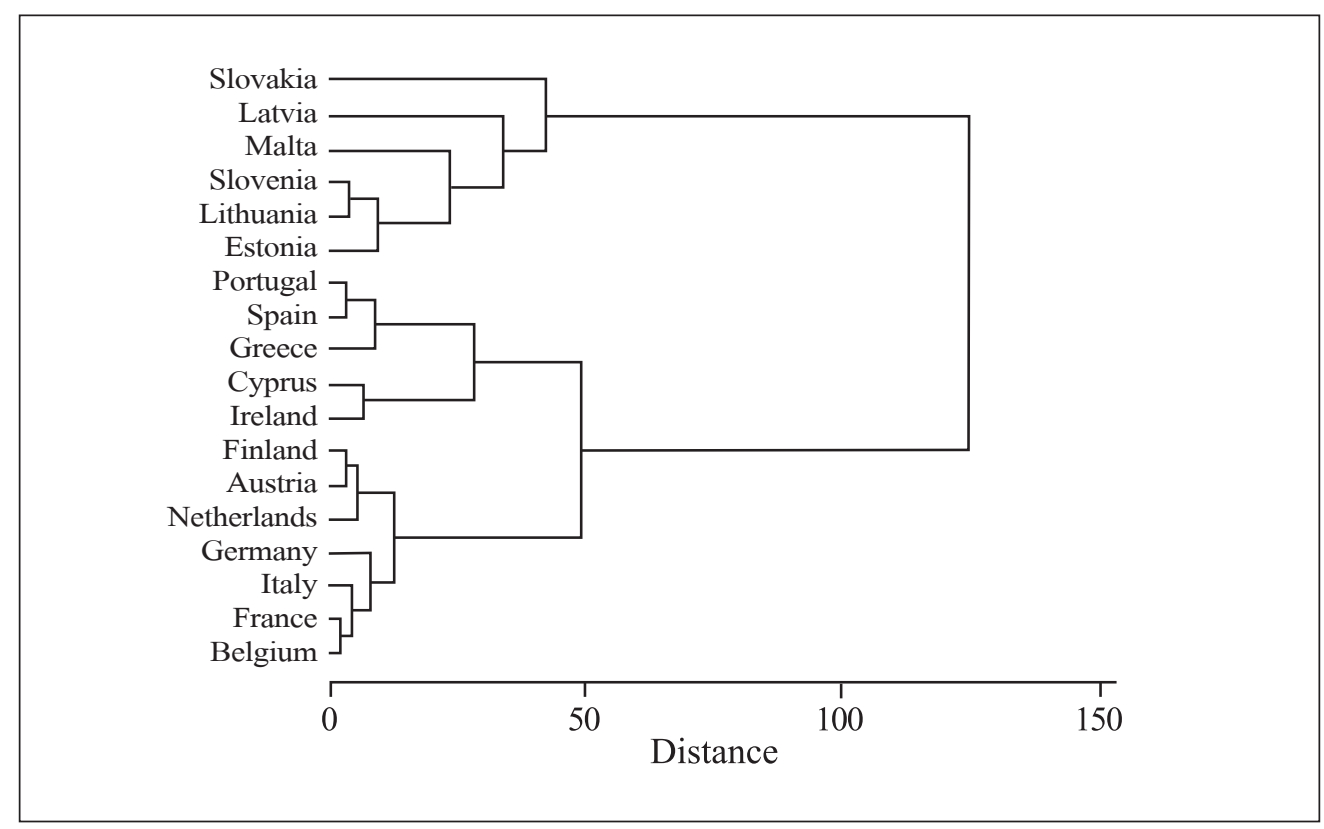


Figure 2c: Euro area 2010

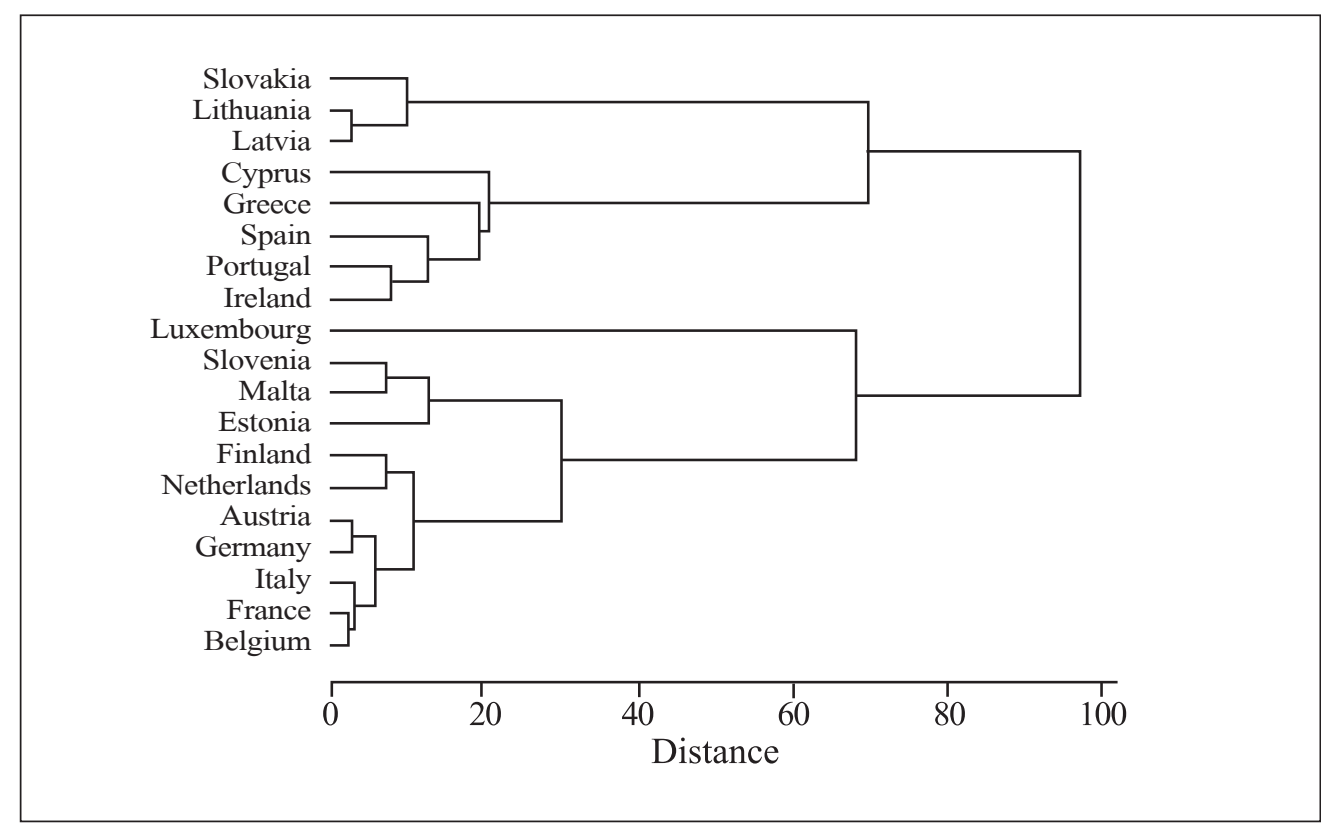

Figure 2d: Euro area 2013

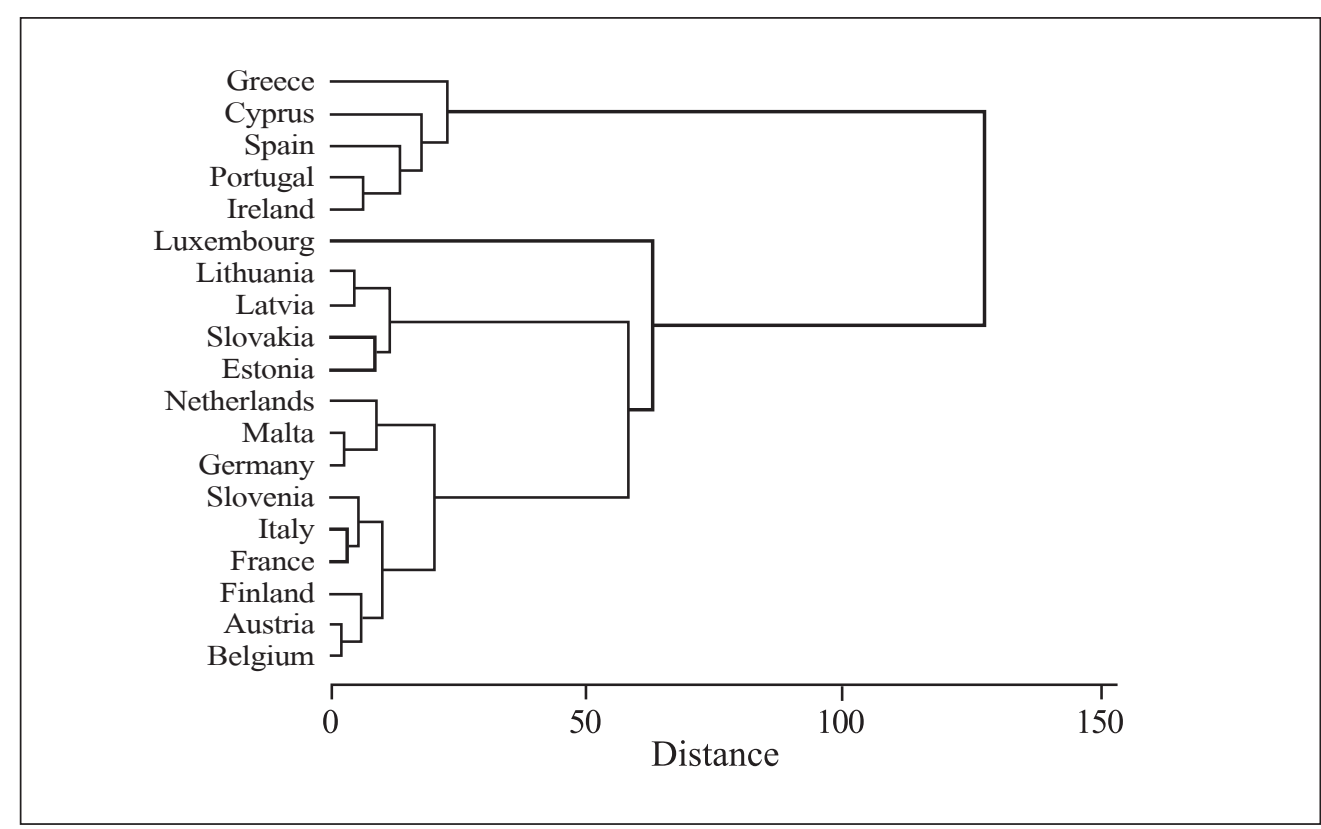

(Note) Cluster analysis using the Ward algorithm. Luxembourg and the house price index variable were dropped due to data gaps in the scoreboard for 2004.

(Source) MIP scoreboard (Eurostat and European Commission), own calculations and presentation. 
Considering now only the current euro-area member states, remarkable insights can also be obtained into the evolution of heterogeneity over the past 10 years. The dendrogram for 2004 (Figure 2a) shows that the core group differs by a wide margin from both the eastern and southern member states. Moreover, in 2007 (Figure 2b), before the financial crisis, the countries now in crisis can clearly be identified as a separate group, although the most marked distance is still that occurring between the core countries and the group of Eastern European countries. By 2010 (Figure 2c), three countries (Malta, Slovenia, and Estonia) from the eastern peripheral group are seen to be approaching the core cluster, even though they still remain identifiable therein as a homogeneous group. Meanwhile, the countries of the southern peripheral group move away from the core group (Figure 2c). Finally, in 2013, they are clustered far from both the eastern periphery and the core (Figure 2d).

\section{B. Results of the Fuzzy C-means algorithm}

According to the results of the Ward method, the countries of the Eastern European periphery and the GIPS countries (plus Cyprus and Croatia) clearly differ from the core group in 2013. Looking at the bottom of the dendrogram in Figure 1, further differentiations within the core group itself seem possible. At this point, the advantages of the FCM clustering algorithm can be used to calculate degrees of membership instead of the explicit assignment of a country to a cluster, as previously undertaken. The countries are therefore each assigned by a certain percentage to all clusters. Assuming again three clusters in the EU-28, the cluster analysis allows a more accurate assessment of countries' extent of belonging to the respective groups (Table 2, left).

Measured by the highest degrees of membership, the FCM algorithm largely confirms the cluster structure of Figure 1. However, Slovakia is instead assigned to cluster 2 of the Eastern European countries and Italy to cluster 3 of the GIIPS countries, which seem both geographically and economically plausible. Italy especially is often considered one of the crisis countries in terms of declining competitiveness, rising debt levels, and increasing unemployment rates. Furthermore, it is striking that Hungary, the only country from the 2004 EU enlargement in cluster 1, has a relatively low level of membership in this cluster and is relatively similar to all clusters. Moreover, Italy is added to cluster 3 but has a slightly lower coefficient for cluster 1. Croatia, the youngest member of the EU, has the greatest similarity to the crisis countries due to its recent poor 
economic situation.

Table 2. Cluster membership of the EU in 2013

\begin{tabular}{|l|c|c|c|c|c|c|c|}
\hline \multirow{2}{*}{ Country } & \multicolumn{2}{|c|}{ Degree of membership if $\boldsymbol{c}=\mathbf{3}$} & \multicolumn{3}{|c|}{ Degree of membership if $\boldsymbol{c}=\mathbf{4}$} \\
\cline { 2 - 7 } & Cluster 1 & Cluster 2 & Cluster 3 & Cluster 1 & Cluster 2 & Cluster 3 & Cluster 4 \\
\hline Belgium & 0.592 & 0.273 & 0.135 & 0.379 & 0.384 & 0.161 & 0.075 \\
\hline Bulgaria & 0.274 & 0.607 & 0.119 & 0.191 & 0.184 & 0.557 & 0.068 \\
\hline Czech Republic & 0.316 & 0.544 & 0.140 & 0.230 & 0.321 & 0.364 & 0.085 \\
\hline Denmark & 0.568 & 0.265 & 0.167 & 0.481 & 0.268 & 0.158 & 0.093 \\
\hline Germany & 0.622 & 0.249 & 0.129 & 0.527 & 0.257 & 0.145 & 0.071 \\
\hline Estonia & 0.290 & 0.569 & 0.141 & 0.203 & 0.180 & 0.533 & 0.084 \\
\hline Ireland & 0.241 & 0.217 & 0.542 & 0.190 & 0.261 & 0.161 & 0.389 \\
\hline Greece & 0.214 & 0.199 & 0.587 & 0.142 & 0.191 & 0.130 & 0.537 \\
\hline Spain & 0.175 & 0.178 & 0.647 & 0.114 & 0.156 & 0.115 & 0.615 \\
\hline France & 0.484 & 0.299 & 0.217 & 0.143 & 0.721 & 0.081 & 0.054 \\
\hline Italy & 0.349 & 0.226 & 0.425 & 0.218 & 0.438 & 0.132 & 0.212 \\
\hline Croatia & 0.263 & 0.260 & 0.477 & 0.195 & 0.296 & 0.181 & 0.328 \\
\hline Cyprus & 0.234 & 0.198 & 0.568 & 0.162 & 0.201 & 0.132 & 0.504 \\
\hline Latvia & 0.241 & 0.617 & 0.141 & 0.153 & 0.177 & 0.591 & 0.079 \\
\hline Lithuania & 0.240 & 0.600 & 0.160 & 0.159 & 0.186 & 0.562 & 0.093 \\
\hline Luxembourg & 0.404 & 0.371 & 0.225 & 0.321 & 0.253 & 0.275 & 0.151 \\
\hline Hungary & 0.391 & 0.309 & 0.300 & 0.242 & 0.445 & 0.168 & 0.144 \\
\hline Malta & 0.664 & 0.258 & 0.079 & 0.597 & 0.223 & 0.139 & 0.041 \\
\hline Netherlands & 0.525 & 0.272 & 0.203 & 0.445 & 0.267 & 0.169 & 0.119 \\
\hline Austria & 0.691 & 0.215 & 0.094 & 0.517 & 0.297 & 0.131 & 0.055 \\
\hline Poland & 0.273 & 0.518 & 0.209 & 0.191 & 0.319 & 0.365 & 0.125 \\
\hline Portugal & 0.103 & 0.103 & 0.794 & 0.075 & 0.124 & 0.073 & 0.728 \\
\hline Romania & 0.267 & 0.543 & 0.190 & 0.192 & 0.246 & 0.442 & 0.121 \\
\hline Slovenia & 0.430 & 0.233 & 0.337 & 0.287 & 0.399 & 0.136 & 0.177 \\
\hline Slovakia & 0.270 & 0.572 & 0.159 & 0.197 & 0.255 & 0.448 & 0.100 \\
\hline Finland & 0.502 & 0.277 & 0.221 & 0.341 & 0.354 & 0.174 & 0.131 \\
\hline Sweden & 0.444 & 0.383 & 0.173 & 0.366 & 0.245 & 0.280 & 0.109 \\
\hline United Kingdom & 0.431 & 0.340 & 0.228 & 0.299 & 0.327 & 0.231 & 0.144 \\
\hline
\end{tabular}

(Note) Cluster analysis using FCM algorithm; $c$ : number of clusters; highest degrees of membership are highlighted in gray.

(Source) MIP scoreboard (Eurostat and European Commission), own calculations and presentation. 
Further differentiation is possible if the EU-28 is separated into four clusters (Table 2 , right). Now cluster 2, except Italy, only comprises countries from the former core group (Belgium, France, Italy, Hungary, Slovenia, Finland, and the UK). Hence, when allowing for some heterogeneity within the clusters, the previous analysis confirms the assumption of three major distinct groups within the EU-28: the Northern European economies, the countries of EU enlargement, and the southern peripheral crisis countries.

\section{Indicators defining the core and the periphery}

The current disparities in Europe are thus confirmed very clearly by cluster analysis. Now, taking a closer look at the single indicators should help to clarify the characteristics and causes of the north-east-south division described above in greater detail. Table 3 shows the average indicator values for the three country groups, ${ }^{9}$ as well as the total euro area. As can be seen, until 2013, significant disparities exist between the core countries and the eastern and southern European peripheries in terms of competitiveness, debt levels, and unemployment.

While the core group as a whole has a positive current account balance averaged over three years, the other two clusters run negative balance sheets. Hence, a stronger euro would suit the core countries, whereas the two peripheral groups could clearly benefit from a weaker currency. This problem can also be seen on the capital account side, where large negative net foreign investment positions are found in the latter group. It is striking that both the southern periphery and Eastern European countries are far below the MIP threshold of $-35 \%$. This can at least partly be seen as an indication of an economic catching-up process. However, the high external liabilities, particularly of the crisis countries, still represent a high risk because they consist a large extent of debt rather than FDI inflows (Fischer and Hobza 2014, European Commission 2015a).

\footnotetext{
${ }^{9}$ For the exact cluster classification below, the results of FCM clustering (Table 2, left) are used.
} 
Table 3. Features of the identified clusters in 2013

\begin{tabular}{|c|c|c|c|c|c|c|c|c|c|c|c|}
\hline & 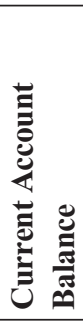 & 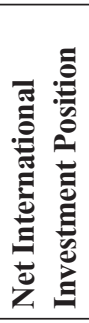 & 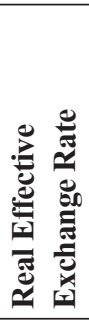 & 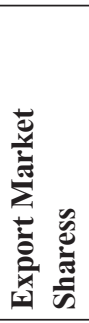 & 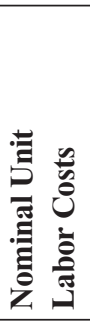 & 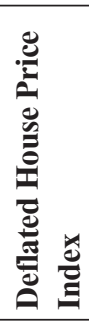 & 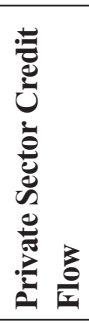 & 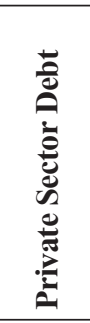 & 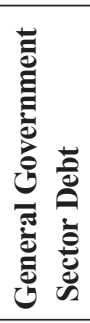 & 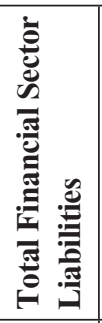 & 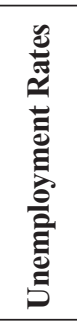 \\
\hline Thresholds & $\begin{array}{l}-4 \% \\
\text { and } \\
6 \%\end{array}$ & $-35 \%$ & $\begin{array}{c}+/-5 \% \\
(\mathrm{EA}) \\
\text { and } \\
\text { (non- } \\
\text { EA) }\end{array}$ & $-6 \%$ & $\begin{array}{c}9 \% \\
\text { (EA) } \\
\text { and } \\
12 \% \\
\text { (non- } \\
\text { EA) }\end{array}$ & $6 \%$ & $14 \%$ & $133 \%$ & $60 \%$ & $16.5 \%$ & $10 \%$ \\
\hline Core group & 2.1 & 10.4 & -0.6 & -14.5 & 6.2 & -2.5 & 0.1 & 140.4 & 83.1 & -4.3 & 7.4 \\
\hline $\begin{array}{l}\text { Eastern } \\
\text { periphery }\end{array}$ & -1.3 & -55.9 & 0.7 & 10.6 & 7.2 & 3.4 & 2.9 & 85.4 & 35.5 & 3.0 & 13.1 \\
\hline $\begin{array}{l}\text { Southern } \\
\text { periphery }\end{array}$ & -2.0 & -118.3 & -2.0 & -14.4 & -4.5 & -5.4 & -6.2 & 224.3 & 124.1 & -10.1 & 17.7 \\
\hline Euro area & 0.5 & -26.6 & -0.6 & -8.3 & 3.8 & -1.6 & 0.4 & 162.3 & 80.7 & -3.6 & 11.2 \\
\hline
\end{tabular}

(Note) EA: euro area.

(Source) MIP scoreboard (Eurostat and European Commission), own calculations and presentation.

On the other hand, the real devaluation and reduction in unit labor costs in the southern periphery over the three years prior to 2014 seem to be less of a concern. This was a necessary adaptation that led to better competitiveness of the Southern European crisis countries. However, it again reflects the dilemma of current monetary policy that low inflation or even deflation is necessary to regain competitiveness in the southern periphery while for the rest of the euro area, an inflation rate of more than $2 \%$ would have to be sought for this purpose. Therefore, a single monetary policy with an average inflation target of $2 \%$ is not equally suitable for all countries. On the part of the core countries and the eastern periphery, unit labor costs increased in this period.

Apart from some Eastern European countries, export market shares decreased from 2009 to 2013 in all countries. Therefore, even the average of all euro-area countries is below the threshold of $-6 \%$ in this period. However, this development can also be 
explained by changes in the global economic situation and the larger export market shares of emerging economies in Asia. The observation of individual country values for this indicator is not very productive.

Rather, a comparison with the average loss of the euro area makes sense (Gros and Giovannini 2014). According to the 2013 scoreboard, 17 EU countries exceed the threshold. However, compared with the average loss of export market shares especially, the situations of Greece and Cyprus, as well as that of Finland, with losses considerably more than twice the average, are worrying (European Commission 2015b).

Although most core countries also exceed the private and public sector debt thresholds, with limits of $133 \%$ and $60 \%$ respectively, they are still well below the extreme values of the countries of the southern periphery (with averages of $224 \%$ and $124 \%$ respectively). In contrast, the Eastern European countries are at much lower and harmless levels (an average of $85 \%$ and 35\%). However, while the negative private credit flows in the southern periphery can be seen - at least for Spain, Portugal, and Ireland - as a sign of private debt reduction, this has not yet happened in Greece (European Commission 2015b). The core and east of the euro area differ in their private sector credit flows at a low level and only slightly from each other. Overall, despite ECB's expansionary monetary policy, a weak demand for credit has so far undermined the intended effect on growth.

The change in the inflation-adjusted house price indicator, which is intended to show the risk of price bubbles in the real estate market, develops differently between the country groups. Besides the significant negative corrections of previous years in the Southern European countries and apart from slight increases in Germany and the Netherlands, the house price indicator also declines moderately in the core countries. The positive average in the Eastern European countries is caused by increases in Estonia and Latvia, which are more than four times as high as the euro-area average.

Unemployment rates still differ greatly between country groups. While they are moderate at $7.4 \%$ in the core group, they are at $17.7 \%$ in the southern periphery. In the crisis countries, and in Croatia particularly, youth unemployment has reached record levels of close to or above $40 \%$. Ongoing fiscal austerity and the expectation of only weak economic growth worsen the prospects of a quick improvement in the situation (European Commission 2015b). Against this background, it is difficult to say whether and when the ECB will be able to reverse its low interest rate policy in favor of the Southern European crisis economies. This underlines the need for effective economic policy measures in these countries. 


\section{Robustness}

The previous division into groups was initially based on an equally weighted use of all 11 scoreboard indicators. Therefore, the similarity in current account balances was assumed to be just as important as the similarity in lending or unemployment rates. However, aside from this assumption, it is important to know which disparities are potentially more dangerous than others and which variables might have common explanatory power. Ultimately, a differently weighted or modified number of indicators might explain the core-periphery structure. Thus, in accordance with Kozluk (2005), we carry out PCA, which reduces the number of 11 original variables to three underlying main components that explain $70 \%$ of the total variation. High values for the first principal component generally correspond to declining unit labor costs and housing prices, a negative net international investment position, negative private sector credit flows, and a decrease in total financial sector liabilities, as well as high general government debt and a high unemployment rate. In contrast, the second principal component correlates strongly and positively with the indicators for current account and private debt levels and negatively with export market share. A graphical representation of the first two principal components in Figure 3 shows that such an analysis identifies the same three clusters as in the previous cluster analysis. (The third principal component, which is highly correlated with the real exchange rate, was not shown for reasons of clarity of illustration but would not change the cluster structure.) Also visible is the unclear attribution of Italy and Hungary, which are found lying between two groups, as well as the classification of Luxembourg as an outlier. 
Figure 3. Country groups according to the first two principal components

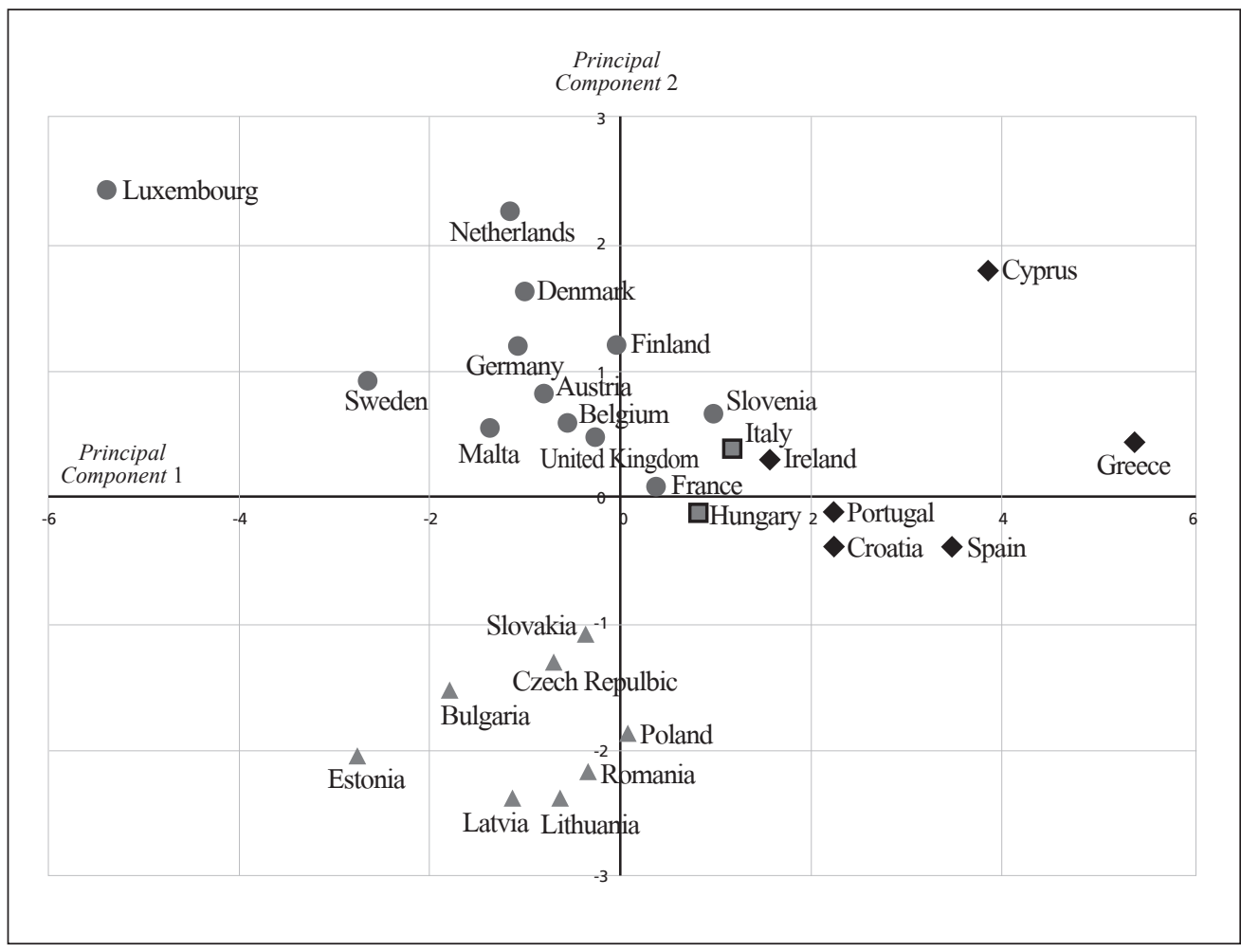

(Note) The correlation matrix between variables and main components and the cumulative variance explained can be found in Appendix 2.

(Source) MIP scoreboard (Eurostat and European Commission), own calculations and presentation.

\section{Policy Suggestions}

\section{A. Suitability for EMU membership}

Our results indicate that recent economic developments in Denmark, the UK, and Sweden are similar to those in the core countries of the euro area. In particular, all cluster specifications suggest that Denmark and Sweden exhibit strong similarities with Malta, the Netherlands, and Germany. Based on these results, the functioning of the EMU would not be impaired by the accession of these countries. Hence, our findings do not 
provide economic justification for the countries' opting out decisions and thus clearly differ from the earlier results of Artis and Zhang (2002). But citizens of Denmark, the UK, and Sweden have always been skeptical towards the euro primarily for social and political rather than for economic reasons (see Müller-Peters et al. 1998 for a crossnational study on these factors). Issues like national pride and identity seem to play a crucial role for the attitude of a country towards the euro (Müller Peters 1998). In this regard, the first referendum decisions of Denmark and Sweden to retain their national currencies could be attributed to a more general feeling of meddling by the European Union. In the case of Denmark, the EMU referendum debate was influenced by other political issues like immigration policy (see Bering 2000 for the case of Denmark and Sunnus 2004 for Sweden). Since then, the Eurobarometer frequently confirmed that the degree of skepticism against the EMU is highest among the Danish, Swedish and British population compared to other member states of the European Union.

Resistance may have increased further due to the fact that the majority of voting power in the European Union is now held by EMU member states. This links European decision-making with the common needs of the euro area and its current crisis, which may also explain, why the UK will rather hold referendum about the withdrawal from the European Union as a whole. In general, skepticism towards the European Union and its decision-making process is a phenomenon common across all EU member states. However, in the northern European countries such as the UK, Denmark, and Sweden this skepticism focusses primarily on currency matters (Condruz-Băcescu 2014). The experience from the euro area crisis even has worsened this situation since the deteriorating economic conditions in other member countries have additional negative impacts on domestic public attitudes towards the European Union (Ioannou, Jamet, and Kleibl 2015).

Those countries at the southern euro area periphery are already part of the monetary union. This group is significantly different from the rest with regard to many indicators, thereby causing existential problems for the functioning and stability of the euro area as a whole such that even its continued existence in the current constellation is at risk. If these countries remain inside the monetary union this is likely to further reduce the attractiveness of the euro, in particular for stronger economies like the UK, Denmark and Sweden.

The Eastern European group also differs from the core group, so it would be difficult to define a single monetary policy. However, these disparities should not be considered solely negative. Indeed, although there is a relatively high unemployment rate, at the 
same time, those economies gain export market share and run only moderate current account deficits. Moreover, they historically have very low private and public debt, which makes them much less prone to solvency crises than southern EMU member states.

\section{B. Achieving greater homogeneity in the EMU}

The analysis has shown that the current euro area comprises countries with very diverse features. Hence, with respect to a "one size fits all" monetary policy considering union-wide average values, basically two possible conclusions emerge. The most obvious one would be the break-up of the existing euro area offering the chance for countries suffering from the crisis to devaluate their new domestic currencies. From the perspective of a smoothly working monetary union, this is what our results clearly suggest. However, the actual decision of countries to participate in the euro area (or even in the EU) should also depend on country specific considerations such as network externalities and switching costs (Dowd and Greenaway 1993), which are beyond the scope of this article.

If, on the other hand, these countries were to retain the euro for political reasons, our results show that it would be essential for core and peripheral groups to converge regarding the MIP indicators. To achieve such convergence within the current euro area, internal devaluation and structural reforms in this case are thought of as important means of adjustment (Shambaugh 2012). Figure 4 shows recent developments in selected MIP indicators for the previously defined clusters. At first glance, reforms appear to be successful and disparities between country groups tend to resolve. For example, nominal unit labor costs in the southern periphery have declined since 2008 (Figure 4a). Due to falling wages and prices, these countries have experienced a real depreciation (see also Table 3), which has helped them regain their price competitiveness to some extent. However, the corresponding current account improvements (Figure 4b) are based predominantly on crisis-related import reductions, making them unsustainable in the case of economic recovery (European Commission 2015a, 5). If one also takes into account that the GIIPS countries appreciated between 1995 and 2007 by $30 \%$ relative to the remaining EMU member states (Sinn 2013, 3), a further substantial readjustment of relative prices seems unavoidable to rebalance current accounts in the long run (Kang and Shambaugh 2013, 18). 
To permanently reestablish the competitiveness of the southern periphery, further wage adjustments thus need to be supplemented by productivity gains (Frankel 2015, 431). Moreover, the scoreboard analysis shows that external imbalances are only one part of the problem. Besides low exports, also restrained private and government spending and lack of investment currently contributes to persistent weak aggregate demand in the GIIPS countries. Growth and employment are suffering from the ongoing private deleveraging and consolidation of public finances in addition to the deflationary environment. Overcoming this weakness in demand by promoting public and particularly private investments, as conducted by the so-called Juncker plan, appears to be one step in the right direction. If it succeeded in raising productivity, unit labor costs could further be reduced, aggregate demand increased, and the still high unemployment will continue to fall (Figure 4d). Moreover, such investment driven growth is essential to consolidate public budgets and could contribute to their ongoing improvement, which is apparent in Figure 4c.

As a baseline for the needs of the south described above, far-reaching structural reforms influencing competitiveness, growth, and employment through a variety of short- and long term channels would be indispensable. Even in a highly integrated euro area, positive spillovers can indeed emanate from coordinated structural reforms for core and peripheral country groups (European Commission 2014b). 
Figure 4. Average values of selected indicators

Figure 4a. Nominal unit labor costs, year-on-year change

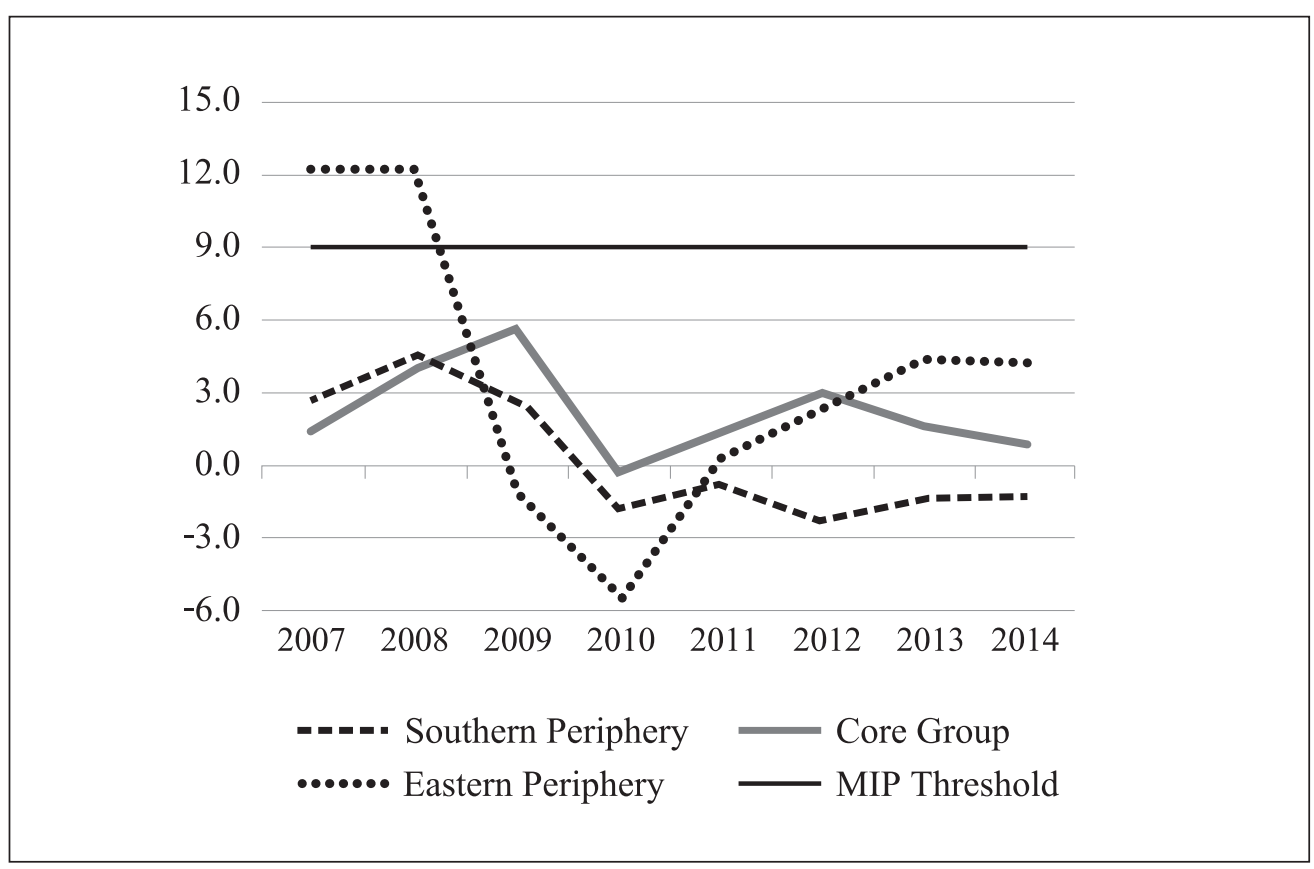

(Note) MIP threshold: 9\%.

(Source) Eurostat, own calculations. 
Figure 4b. Current account balance

(\% of GDP)

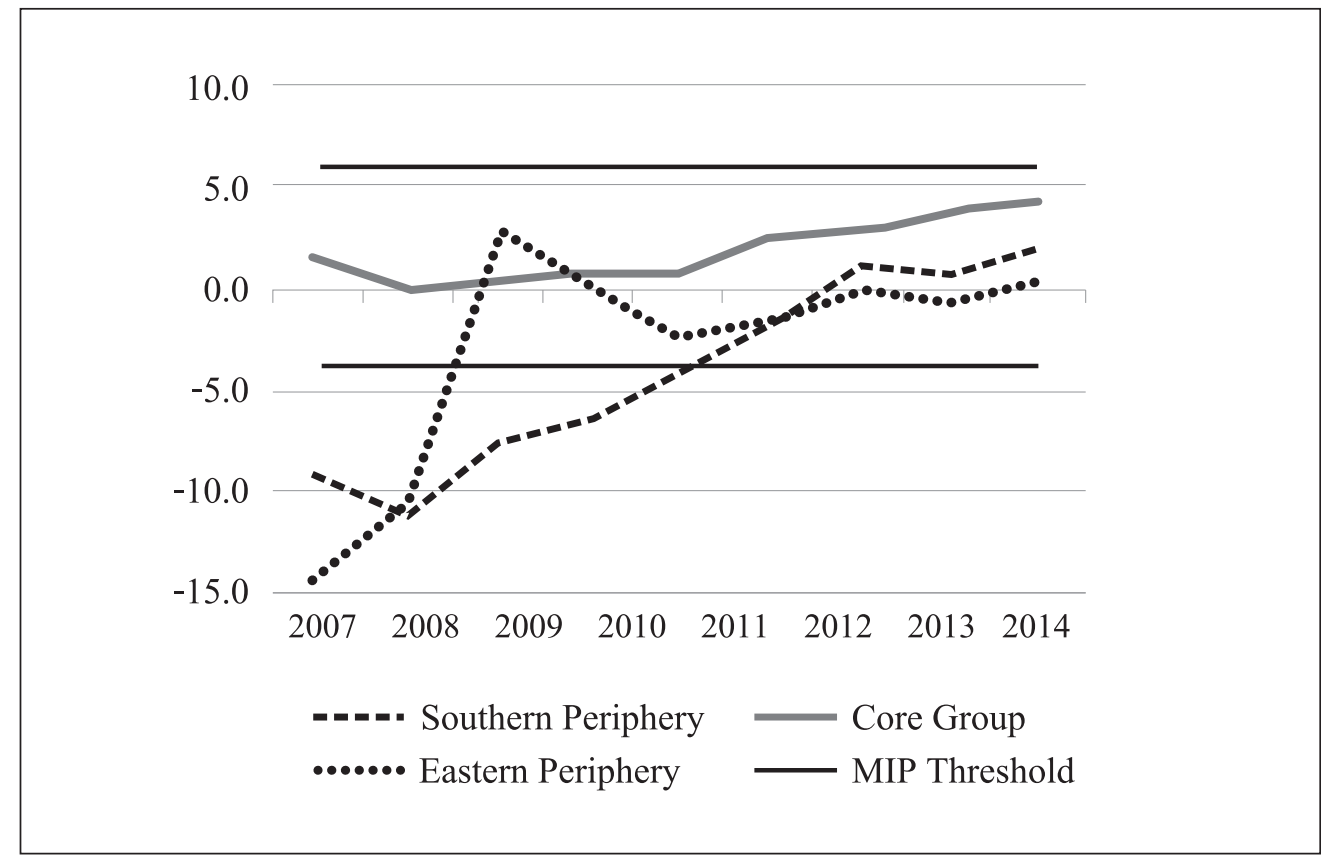

(Note) MIP threshold: $-4 \%$ and $6 \%$.

(Source) OECD, own calculations. 
Figure 4c. Fiscal deficits

(\% of GDP)

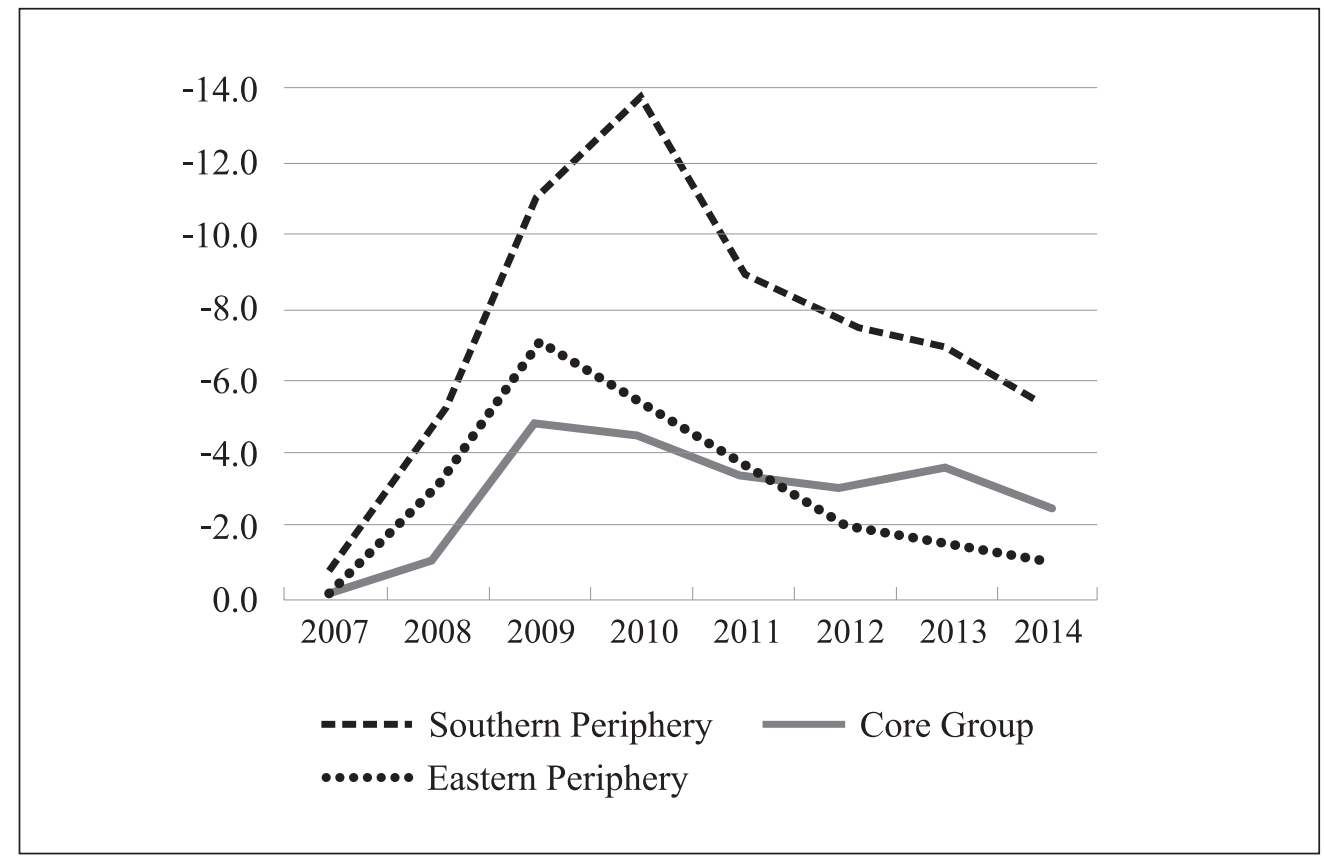

(Note) Annual data.

(Source) Eurostat, own calculations. 
Figure 4d. Unemployment rate

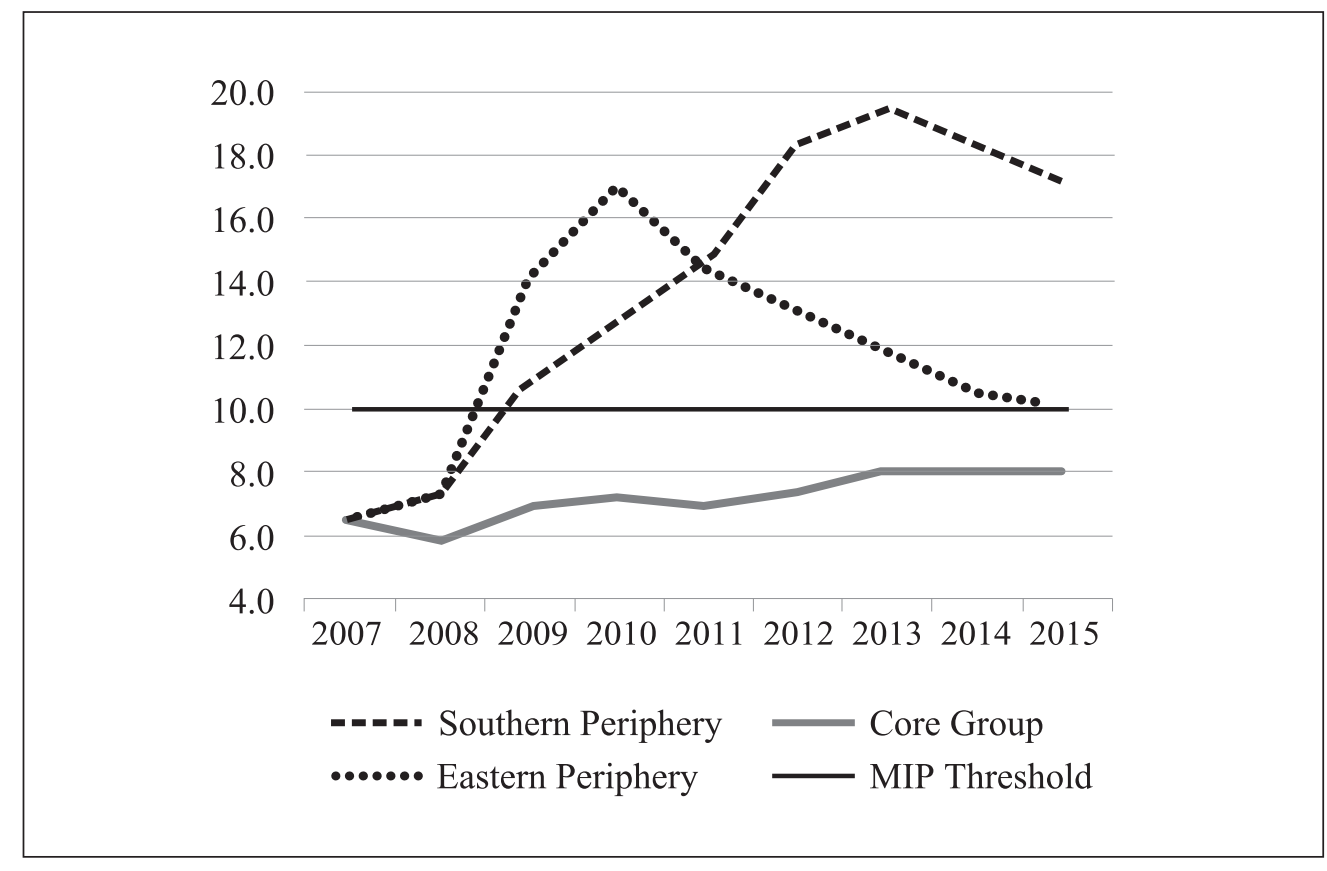

(Note) MIP threshold: $10 \%$.

(Source) Eurostat, own calculations.

\section{Conclusion}

In this paper we have used the MIP scoreboard indicators to investigate cluster structures within the EU and EMU. By applying two different cluster methods we found large heterogeneities between the southern and eastern periphery, and the core countries in central Europe. Hence, our findings are in sharp contrast to the endogeneity hypothesis of an optimal currency area and also question the commitment of an ever closer union at least for all countries. Our results not only confirm earlier research on the economic disparities between the GIIPS and the core countries during the euro crisis but may also serve as an indication of how well an EU member state fits into the monetary union. Regarding the economic suitability, on the one hand, the clustering would suggest the UK to join the euro area rather than holding a referendum about the so-called BREXIT 
from the EU. On the other hand, the results support the view that most of the deficit countries, especially Greece, should rather exit the euro area, as their membership seriously impairs the efficiency and stability of the monetary union. For the euro area in its current formation, our analysis highlights the need for fundamental structural reforms in order to reestablish the well-functioning of EMU. Therefore, our approach helps detecting significant disparities across countries and finding adequate policy responses for each group of countries exhibiting different economic features. Future research may carry out cluster analysis on the upcoming MIP scoreboard data to evaluate, weather the EMU succeeds to increase the degree of homogeneity across member states.

Received 22 December 2015, Revised 29 February 2016, Accepted 26 April 2016

\section{References}

Artis, Michael J., and Wenda Zhang. "Core and Periphery in EMU: A Cluster Analysis." Economic Issues 6 (2001): 39-59.

Artis, Michael J., and Wenda Zhang. "Membership of EMU: A Fuzzy Clustering Analysis of Alternative Criteria." Journal of Economic Integration 17 (2002): 54-79.

Backhaus, Klaus, Bernd Erichson, Wulf Plinke, and Rolf Weiber."Multivariate Analysemethoden, Eine anwendungsorientierte Einführung." $12^{\text {th }}$ ed. Berlin: Springer, 2008.

Bayoumi, Tamim, and Barry Eichengreen. "Shocking aspects of European monetary integration." Adjustment and Growth in the European Monetary Union, edited by Torres, Francisco, and Francesco Giavazzi. Cambridge: Cambridge University Press, 1993.

Bayoumi, Tamim, and Barry Eichengreen. "One Money or Many? Analysing the Prospects for Monetary Unification in Various Parts of the World." Princeton Studies in International Finance 76 (1994).

Bayoumi, Tamim, and Barry Eichengreen. "Ever closer to heaven? An optimumcurrency-area index for European countries." European Economic Review 41 (1997): 761-770. 
Beetsma, Roel, and Harald Uhlig. "An Analysis of the Stability and Growth Pact." The Economic Journal 109 (1999): 546-571.

Bergs, Siegfried. Optimalität bei Clusteranalysen: Experimente zur Bewertung numerischer Klassifikationsverfahren. Münster, 1981.

Bering, Henrik. "Denmark, the Euro, and Fear of the Foreign." Policy Review (2000): 63-72.

Bezdek, James C. Pattern Recognition with Fuzzy Objective Function Algorithms. New York: Plenum Press, 1981.

Boreiko, Dimitri. "EMU and accession countries: Fuzzy cluster analysis of membership." International Journal of Finance and Economics 8 (2003): 309-325.

Caporale, Guglielmo M., Roberta De Santis, and Alessandro Girardi. "Trade intensity and output synchronisation: On the endogeneity properties of EMU." Journal of Financial Stability 16 (2014): 154-163.

Condruz-Bacescu, Monica. "Euroscepticism Across Europe: Drivers and Challenges." European Journal of Interdisciplinary Studies 6 (2014): 52-59.

De Haan, Jakob, Robert Inklaar, and Richard Jong-A-Pin. "Will Business Cycles in the Euro Area Converge? A Critical Survey of Empirical Research." Journal of Economic Surveys 22 (2007): 234-273.

Dowd, Kevin, and David Greenaway. "Currency Competition, Network Externalities and Switching Costs: Towards an Alternative View of Optimum Currency Areas." The Economic Journal 103 (1993): 1180-1189.

Eichengreen, Barry. "The Breakup of the Euro Area." Europe and the Euro, edited by Alesina, Alberto and Francesco Giavazzi, 11-41. Chicago: University of Chicago Press, 2010 .

European Commission. "EMU@10, Successes and challenges after ten years of Economic and Monetary Union." European Economy 2 (2008).

European Commission. "Scoreboard of the surveillance of macroeconomic imbalances." European Economy Occasional Papers 92 (2012).

European Commission. "Focus: Growth differences between EA Member States since the crisis." Quarterly Report on the Euro Area 13 (2014a): 7-20. 
European Commission. "Focus: Cross-border spillovers in the euro area." Quarterly Report on the Euro Area 13 (2014b): 7-22.

European Commission. "Macroeconomic Imbalances, Main Findings of the In-Depth Reviews 2015." European Economy Occasional Papers 228 (2015a).

European Commission. “Alert Mechanism Report.”(2015b).

Feldstein, Martin. "The Political Economy of the European Economic and Monetary Union: Political Sources of an Economic Liability." Journal of Economic Perspectives 11 (1997): 23-42.

Fischer, Jonas, and Aleksandr Hobza. "Balancing Imbalances: Integrated Surveillance and the Role of the MIP" Banca d'Italia: Fiscal Policy and Macroeconomic Imbalances, Workshops and Conferences 16 (2014).

Frankel, Jeffrey. "The euro crisis: Where to from here?" Journal of Policy Modeling 37 (2015): 428-444.

Frankel, Jeffrey, and Andrew K. Rose. "The Endogeneity of the Optimum Currency Area Criteria." The Economic Journal 108 (1998): 1009-1025.

Gächter, Martin, and Aleksandra Riedl. "One money, one cycle? The EMU experience." Journal of Macroeconomics 42 (2014): 141-155.

Gros, Daniel, and Alessandro Giovannini. "The "Relative" Importance of EMU Macroeconomic Imbalances in the Macroeconomic Imbalance Procedure.” Documenti IAI 02 Istituto Affari Internazionali (2014).

Gruber, Torsten, and Renate Ohr. "The significance of different financial structures in EMU." European economic and monetary union: Regional and global challenges, edited by Caesar, Rolf and Hans-Eckhart Scharrer. Baden-Baden, 2001: 281-300.

Hall, Peter A. "The Economics and Politics of the Euro Crisis." German Politics 21 (2012): 355-371.

Horstmann, Winfried, and Friedrich Schneider. "Deficits, Bailout and Free Riders: Fiscal Elements of a European Constitution.” Kyklos 47 (1994): 355-383.

Ioannou, Demosthenes and Jean-François Jamet, and Johannes Kleibl. "Spillovers and Euroscepticism." ECB Working Paper Series 1815 (2015). 
Jonung, Lars, and Eoin Drea. 'It Can't Happen, It's a Bad Idea, It Won't Last: U.S. Economists on the EMU and the Euro, 1989 2002." Econ Journal Watch 7 (2010): 4-52.

Kang, Joong S., and Jay Shambaugh. "The Evolution of Current Account Deficits in the Euro Area Periphery and the Baltics: Many Paths to the Same Endpoint." IMF Working Paper 169 (2013).

Kaufman, Leonard, and Peter J. Rousseeuw. Finding Groups in Data, An Introduction to Cluster Analysis. New York, 2005.

Knedlik, Tobias. "The Usefulness of the Scoreboard of the Macroeconomic Imbalances Procedure in the European Union: Potentials for Reform." Swedish Institute for European Policy Studies European Policy Analysis (2015):14.

König, Jörg, and Renate Ohr. "Different Efforts in European Economic Integration: Implications of the EU Index.” Journal of Common Market Studies 51 (2013): 1074-90.

Kozluk, Tomasz. "CEEC Accession Countries and the EMU - An Assessment of Relative and Readiness for Euro-Area Membership." Journal of Economic Integration 20 (2005): 439-474.

Lane, Philip R. "The European Sovereign Debt Crisis." Journal of Economic Perspectives 26 (2012): $49-68$.

Lehwald, Sybille. "Has the Euro Changed Business Cycle Synchronization? Evidence from the Core and the Periphery." Empirica 40 (2013): 655-684.

Mongelli, Franceso Paolo. "European economic and monetary integration and the optimum currency area theory.” European Economy Economic Papers 302 (2008).

Müller-Peters, Anke. "The significance of national pride and national identity to the attitude towards the single European currency: A Europe-wide comparison." Journal of Economic Psychology 19 (1998): 701-719.

Müller-Peters, Anke, Roland Pepermans, Guido Kiell, Nicole Battaglia, et al. "Explaining attitudes towards the euro: Design of a cross-national study." Journal of Economic Psychology 19 (1998): 663-680.

Ohr, Renate. "The Euro in its Fifth Year: Expectations Fulfilled?" The Price of the Euro, edited by Jonas Ljungberg, 59-69. Basingstoke and New York: Palgrave Macmillan, 
2004.

Pentecôte, Jean-Sébastien, and Marylin Huchet-Bourdon. "Revisiting the core-periphery view of EMU." Economic Modelling 29 (2012): 2382-2391.

Quah, Chee-Heong. "Revisiting business cycles in the Eurozone: A fuzzy clustering and discriminant approach." Acta Oeconomica 64 (2014): 161-180.

Rozmahel, Petr, Ludek Kouba, Ladislava Grochová, and Nikola Najman. "Integration of Central and Eastern European Countries: Increasing EU Heterogeneity?" WWW for Europe Working Paper 9 (2013).

Shambaugh, Jay. “The Euro's Three Crises.” Brookings Papers on Economic Activity 44 (2012): 157-231.

Sinn, Hans-Werner. "Verantwortung der Staaten und Notenbanken in der Eurokrise, Gutachten im Auftrag des Bundesverfassungsgerichts." ifo Schnelldienst, special edition, June (2013): 3-33.

Sunnus, Milena. "Swedish Euroscepticism: Democracy, Sovereignty and Welfare." European Studies 20 (2004): 193-205.

Wang, Weina, and Yunjie Zhang. "On fuzzy cluster validity indices.” Fuzzy Sets and Systems 158 (2007): 2095-2117. 


\section{Appendix 1: Dendrogram of the cluster analysis for the EU in 2013}

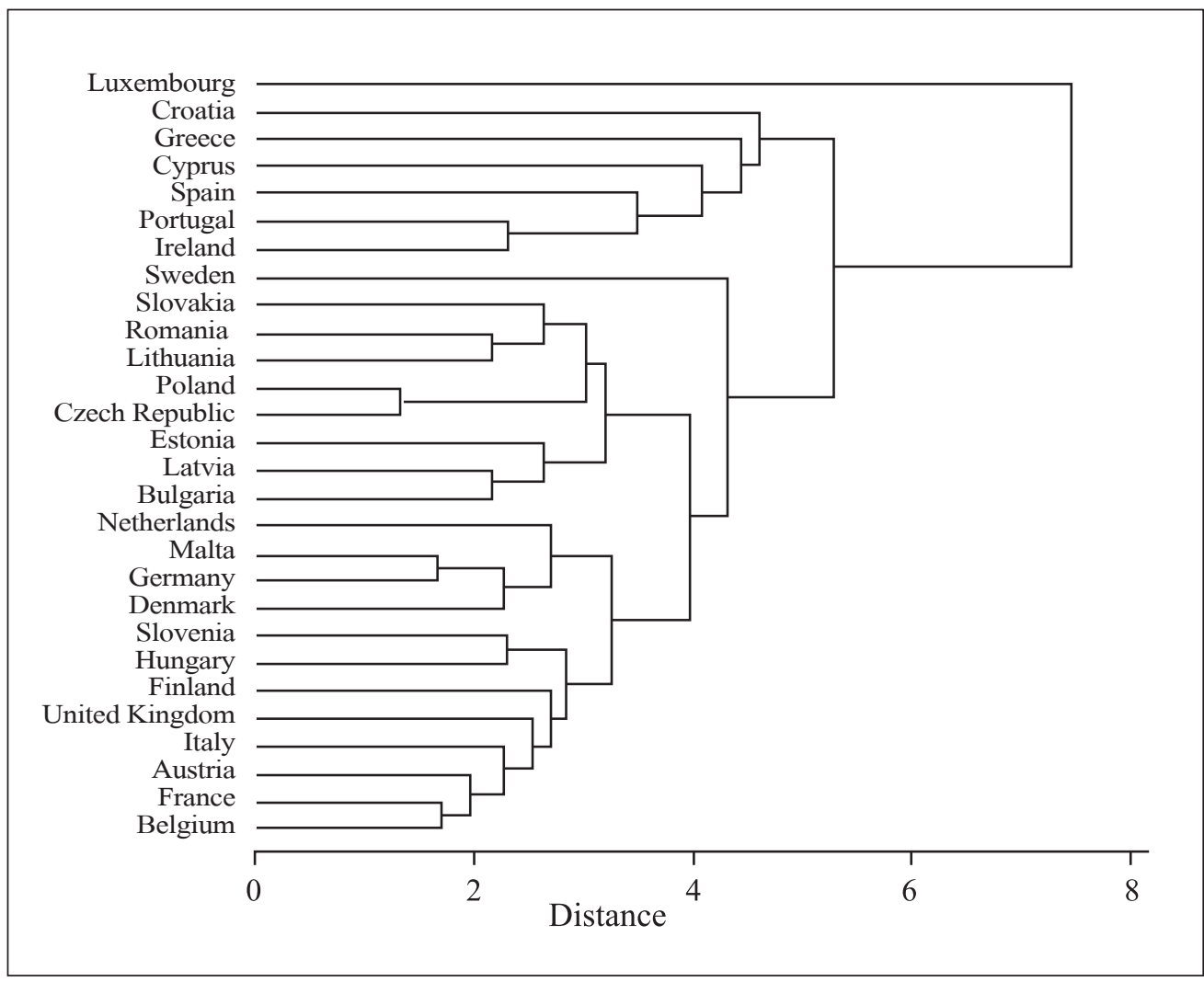

(Note) Cluster analysis using the average linkage algorithm.

(Source) MIP Scoreboard (Eurostat and European Commission), own calculations and presentation. 


\section{Appendix 2: Correlation matrix and cumulative variances}

\begin{tabular}{|l|c|c|c|c|c|}
\hline MIP-Indicators & $\begin{array}{c}\text { Component } \\
\mathbf{1}\end{array}$ & $\begin{array}{c}\text { Component } \\
\mathbf{2}\end{array}$ & $\begin{array}{c}\text { Component } \\
\mathbf{3}\end{array}$ & Component & $\begin{array}{c}\text { Cumulative } \\
\text { variance explained }\end{array}$ \\
\hline $\begin{array}{l}\text { Current Account } \\
\text { Balance }\end{array}$ & -0.496 & 0.564 & -0.308 & 1 & 0.429 \\
\hline $\begin{array}{l}\text { Net Internat. } \\
\text { Investment Position }\end{array}$ & -0.756 & 0.475 & -0.158 & 2 & 0.604 \\
\hline $\begin{array}{l}\text { Real Effective } \\
\text { Exchange Rate }\end{array}$ & -0.467 & 0.102 & 0.730 & 3 & 0.702 \\
\hline $\begin{array}{l}\text { Export Market } \\
\text { Shares }\end{array}$ & -0.483 & -0.677 & 0.144 & 4 & 0.776 \\
\hline $\begin{array}{l}\text { Nominal Unit } \\
\text { Labor Costs }\end{array}$ & -0.860 & -0.095 & -0.116 & 5 & 0.831 \\
\hline $\begin{array}{l}\text { Deflated House } \\
\text { Price Index }\end{array}$ & -0.707 & -0.067 & 0.440 & 6 & 0.877 \\
\hline $\begin{array}{l}\text { Private Sector } \\
\text { Credit Flow }\end{array}$ & -0.771 & 0.087 & -0.093 & 7 & 0.912 \\
\hline Private Sector Debt & -0.029 & 0.715 & 0.306 & 8 & 0.942 \\
\hline $\begin{array}{l}\text { General Government } \\
\text { Sector Debt }\end{array}$ & 0.787 & 0.328 & 0.004 & 9 & 0.971 \\
\hline $\begin{array}{l}\text { Total Financial } \\
\text { Sector Liabilities }\end{array}$ & -0.699 & -0.413 & -0.284 & 10 & 0.990 \\
\hline Unemployment Rate & 0.709 & -0.322 & 0.120 & 11 & 1.000 \\
\hline
\end{tabular}

(Note) Cumulative variance explained for the principal components of the scoreboard indicators in 2013.

(Source) MIP scoreboard (Eurostat and European Commission), own calculations and presentation. 